Columbia Law School

Scholarship Archive

2018

\title{
Competition Law Gone Global: Introducing the Comparative Competition Law and Enforcement Datasets
}

\author{
Anu Bradford \\ Columbia Law School, abradf@law.columbia.edu \\ Adam S. Chilton \\ University of Chicago Law School, adamchilton@uchicago.edu \\ Chris Megaw \\ WilmerHale LLC, cmegaw@gmail.com \\ Nathaniel Sokol \\ Columbia University
}

Follow this and additional works at: https://scholarship.law.columbia.edu/faculty_scholarship

Part of the Antitrust and Trade Regulation Commons, and the Comparative and Foreign Law Commons

\section{Recommended Citation}

Anu Bradford, Adam S. Chilton, Chris Megaw \& Nathaniel Sokol, Competition Law Gone Global: Introducing the Comparative Competition Law and Enforcement Datasets, JOURNAL OF EMPIRICAL LEGAL STUDIES, VoL. 16, P. 411, 2019 (2018).

Available at: https://scholarship.law.columbia.edu/faculty_scholarship/2514

This Working Paper is brought to you for free and open access by the Faculty Publications at Scholarship Archive. It has been accepted for inclusion in Faculty Scholarship by an authorized administrator of Scholarship Archive. For more information, please contact scholarshiparchive@law.columbia.edu. 


\title{
Competition Law Gone Global: Introducing the Comparative Competition Law and Enforcement Datasets*
}

\author{
Anu Bradford ${ }^{\dagger}$ Adam Chilton ${ }^{\ddagger}$ Christopher Megaw $\$$ Nathaniel Sokol ${ }^{* *}$
}

August 17, 2018

\begin{abstract}
Competition law has proliferated around the world. Due to data limitations, however, there is little systematic information about the substance and enforcement of these laws. In this paper, we address that problem by introducing two new datasets on competition law regimes around the world. First, we introduce the Comparative Competition Law Dataset, which codes competition laws in 130 jurisdictions between 1889 to 2010. Second, we introduce the Comparative Competition Enforcement Dataset, which provides data on competition agencies' resources and activities in 100 jurisdictions between 1990 and 2010. These datasets offer the most comprehensive picture of competition law yet assembled and provide a new foundation for empirical research on the legal regimes used to regulate markets.
\end{abstract}

\footnotetext{
* This research is part of a tremendous data gathering effort that has left us indebted to many. We are particularly grateful to the over 100 national competition enforcement agencies that shared data with us as well as to the UNCTAD, the ICN and the ECN for facilitating this effort among their members. Several competition law professionals, students, and colleagues around the world provided invaluable help in this process. The final datasets reflect the outstanding work of over 100 Columbia Law School and the University of Chicago Law School students who helped us retrieve, review, and process the data used in this study over the course of five years and more than 10,000 hours. We gratefully acknowledge the financial support from the National Science Foundation, which funded the first phase of the data gathering. See Collaborative Research: "The Law and Politics of Antitrust in Open Economies," NSF-Law \& Social Sciences grants 1228453 \& 1228483, awarded in September 2012. The coding was subsequently expanded with the generous support of the Columbia Public Policy Grant: "Does Antitrust Policy Promote Market Performance and Competitiveness?", awarded in June 2015, and with the help of the additional financial support from Columbia Law School.

† Henry L. Moses Professor of Law and International Organization, Columbia Law School (abradf@law.columbia.edu).

\# Assistant Professor of Law and Walter Mander Research Scholar, University of Chicago Law School (adamchilton@uchicago.edu).

S Senior Associate, WilmerHale (chris.megaw@wilmerhale.com), JD, Columbia Law School, 2014.

** Law Clerk, United States Bankruptcy Court, Southern District of New York (nate.sokol@gmail.com), JD, Columbia Law School, 2016.
} 


\section{Introduction}

Competition law is one of the most commonly deployed instruments to regulate the operation of markets and is a standard feature of economic policy in developed and developing countries alike. ${ }^{1}$ But as Figure 1 illustrates, this has not always been the case. Canada enacted the world's first modern competition law in 1889, followed by the United States a year later. ${ }^{2}$ From 1900 until the end of WWII, however, only 13 countries adopted competition laws. During the cold war, another 28 countries adopted competition laws. After the fall of the Soviet Union and the transition of many countries to market economies, the number of countries with competition laws exploded. Between 1990 and 2010, 78 countries adopted competition laws. By 2010, our research suggests that 135 jurisdictions-129 countries and 6 regional organizations-had competition laws.

Despite this striking spread of competition law, beyond a few key jurisdictions, there is little systematic data on countries' competition regimes. ${ }^{3}$ In fact, most crossnational empirical studies on the nature and effects of competition law have failed to account for the remarkable variation in competition regimes around the world and instead relied on a binary coding of whether or not any competition law exists on the books. Even fewer studies measure the operation of these laws on the ground, including whether they are complemented with adequate resources and meaningful enforcement efforts.

In this paper, we introduce two new datasets that provide a detailed coding of competition laws and their enforcement around the world. First, the Comparative Competition Law Dataset provides detailed coding on competition law provisions from 131 jurisdictions-126 countries and 5 regional organizations-from the beginning of modern competition law until 2010. ${ }^{4}$ Second, the Comparative Competition Enforcement Dataset provides data on enforcement resources and activities for 100 jurisdictions during

\footnotetext{
${ }^{1}$ Although this area of law is called antitrust law in the United States, we refer to it as competition law because that it is the standard name for the field outside of America and we hope for our datasets to be used by researchers from around the world.

2 Although Canada's competition law from 1889 is generally considered the first modern competition law, we also identified a few earlier competition laws and included them in the dataset. For instance, the dataset includes England's Statute of Monopolies of 1623 and France's Le Chapelier Law of 1791.

3 Part II provides a brief review of this literature.

${ }^{4}$ Appendix 1 provides a list of the jurisdictions included in both datasets.
} 
the years 1990 to 2010. To our knowledge, these datasets represent the most comprehensive effort to collect data on the world's competition law regimes. Both datasets are available for download at www.comparativecompetitionlaw.org.

In order to introduce these new resources, this paper explains the processes used to collect these datasets, describes their coverage, discusses their limitations, and reports several stylized facts about competition law around the world revealed by the data. For instance, to highlight the content of the Comparative Competition Law Dataset, we show the variance in the policy goals that these laws promulgate; document how countries carve out different industries from the scope of these laws; and illustrate how some categories of authority granted by competition statutes have grown over time while others have waned. To highlight the content of the Comparative Competition Enforcement Dataset, we show how Russia and other former members of the USSR have used competition law in a fundamentally different way than other countries; document that, despite the vast proliferation of competition law agencies around the world, most enforcement activities are carried out by a small number of jurisdictions; and compare the regulation of mergers by the United States and the European Union.

By introducing these datasets, our goal is to make two larger contributions. First, these datasets will allow scholars to examine the drivers, diffusion, and impact of these laws. We are therefore aiming to elevate the quality of the many empirical research projects on international competition law that are currently underway or that will be forthcoming. Second, our project provides a template for similar cross-national data collection efforts in other areas of the law. While we are aware of a handful of other projects that have systematically coded specific aspects of countries' legal regimes (Elkins, Ginsburg, \& Melton 2009; Law \& Versteeg 2011; Chang, Garoupa, \& Martin Wells 2018), we are not aware of any existing cross-national datasets that include legal coding and enforcement data that compare to this research project in scope and scale. Our hope is that our efforts inspire other scholars of comparative law to launch similar studies in other fields.

This paper proceeds as follows. In Part 2, we review prior efforts to collect comparative data on competition law. In Part 3, we introduce the Comparative Competition Law Dataset and document several stylized facts about the regulation of competition. In Part 4, we describe the Comparative Competition Enforcement Dataset 
and highlight stylized facts about competition enforcement resources and activities around the world. In Part 5, we briefly conclude.

\section{Prior Data Collection Efforts}

Our project is not the first effort to collect data on competition policy around the world. Instead, there have been dozens of research projects that have reported at least some comparative data on competition law. But although these projects have produced a number of important findings and deserve credit for breaking new substantive and methodological ground, many of these datasets suffer from important limitations. In Appendix 2, we provide a complete list of empirical research in the field of comparative competition law of which we are aware, ${ }^{5}$ but here we briefly summarize the four categories of projects that have reported such comparative competition law data.

The first, and most common, data collection category is a binary coding of whether competition law exists or not in any given country in any given year. For example, Kee \& Hoekman (2007), Petersen (2013), and Gutmann \& Voigt (2014) all simply code countries that have a competition law as " 1 " and countries without as " 0. ." Although a binary variable for the presence of a competition law regime may be appropriate for some applications, this type of data is obviously limited by not accounting for variation in the nature of countries' competition laws or the intensity of their enforcement. This is problematic for many applications because there is tremendous variation in the content of competition laws across countries and over time.

Second, a handful of datasets go beyond a binary measure and capture some of the nuances in the competition laws that countries have adopted. These datasets code whether countries have specific provisions in their competition law. For instance, Hylton \& Deng

\footnotetext{
${ }^{5}$ For Appendix 2, we tried to identify comparative empirical studies that introduce original measures of competition law or policy in more than one country, and exclude studies that rely on existing as opposed to original data. In addition to empirical studies that seek to measure laws and their enforcement, other empirical studies have focused on measuring competition as such (e.g., Aghion et al. 2005). These studies typically rely on data such as industry concentration ratios, price markups, or the Lerner index that measures a firm's market power. Although these studies are relevant to research on competition, we do not review them or include them in Appendix 2.

6 To be more specific, Kee \& Hoekman (2007) collect more detailed enforcement data for a single year, 2000, but rely on a dummy variable in their analyses after noting that "there is no comprehensive data base that indexes cross-country differences in competition law enforcement over our sample period."
} 
(2007) and Nicholson (2008) developed indices that identify the presence or absence of various types of provisions governing, for example, merger regulation, the prohibition of anticompetitive agreements, or abuse of dominance. Notably, Hylton \& Deng (2007) use their data to develop a 30-point index of the overall scope and stringency of national competition laws. ${ }^{7}$ The trade-off when producing this more detailed coding, however, has been having a limited number of countries or years coded. For instance, Nicholson (2008) provides data on 52 countries for just the year 2003, and Hylton \& Deng (2007) provide data on 102 countries for only the years 2001-2004.

Third, a few data collection efforts measure competition enforcement resources and activity. For instance, Clougherty (2010) used data on enforcement budgets to exam trends in competition policy and economic growth. Additionally, the Global Competition Review ("GCR") is an annual commercial publication that ranks competition agencies largely based on their quantitative enforcement record. ${ }^{8}$ Similarly, the World Economic Forum surveys companies actively competing in a market to try and capture countries' overall enforcement efforts based on their "perceived effectiveness of competition policy." "These datasets also are limited in their availability, coverage, and reliability. For example, the GCR database is typically unavailable for public use, the data is limited to a relatively small number of OECD countries for many years, and our research suggests that the data is often unreliable.

Fourth, a few projects have collected a broad range of information on countries' laws, enforcement resources and activities, and institutional features to develop a composite index of competition policy. For instance, Voigt (2009) constructed a set of indicators that reflect both the content of competition laws - including the extent to which these laws reflect an economic approach—and institutional features such as agency

\footnotetext{
7 The Scope Index is available at the "AntitrustWorldWiki", available at <http://www.antitrustworldwiki.com/antitrustwiki/index.php/Main_Page> (last visited August 13, 2018). For an example of research relying on these indices, see Ma (2011).

8 Global COMPETITION REVIEW, http://globalcompetitionreview.com/ (last visited March 7, 2018). For an example of academic research that has relied on the Global Competition Review data, see McCloughan, Lyons, \& Batt (2007).

9 The Global Competitiveness Report, WORLD ECONOMIC FORUM, https://www.weforum.org/reports/theglobal-competitiveness-report-2016-2017-1 (last visited Jan. 2, 2017). For examples of academic research that has relied on the World Economic Forum data, see Krakowski (2005) and Sama (2013).
} 
independence. And perhaps most notably, Buccirossi et al. (2011) developed a composite index that measures a range of features of competition laws, including the size of sanctions available and the expected probability of detection. Given the breadth of their coverage, perhaps unsurprisingly, these datasets have extremely limited coverage. Buccirossi et al. (2011), for example, covers the years 1995-2005 for 13 OECD jurisdictions where data were available. ${ }^{10}$ In other words, they were only able to obtain detailed information from a handful of the worlds' most advanced economies.

Although our datasets have their own limitations, we have sought to go beyond existing datasets by increasing the number of jurisdictions, years, and the variables covered. Importantly, we have separately collected datasets on competition laws and actual enforcement resources and activity. We discuss these datasets in detail in the next two sections.

\section{Comparative Competition Law Dataset}

We now turn to introducing the first of the two new datasets: the Comparative Competition Laws Dataset. First, we explain our process for collecting the data. Second, we explain the coverage of the dataset across countries and over time, as well as the categories of variables that it includes. Third, we discuss the limitations of our data collection efforts. Finally, we use the data to document new stylized facts about the goals, exceptions, and authority contained in competition laws around the world.

\section{A. Collection Process}

The data collection was carried out over the course of six years with the help of over 70 Columbia Law School students. The research team primarily comprised foreign trained law students with relevant legal education and language skills because they brought relevant local and regional knowledge to the project and made it possible to retrieve and code laws that were not available in English.

The process of collecting the data entailed multiple steps. When we began the data collection back in 2011, we first identified all the jurisdictions that had adopted a

\footnotetext{
${ }^{10}$ Voigt (2009) provides data from 1990-2000 for 58 countries, but for a narrow range of variables.
} 
competition law by 2010 - the year prior to when our data collection effort started. We also chose the year 2010 as the end point to ensure that we could reliably identify and obtain copies of competition laws that had been passed around the world, and also verify if those laws subsequently entered into force.

For each of these jurisdictions, the research team identified and collected the entire universe of relevant laws that had been passed dating back to each jurisdiction's first competition law. This included general competition laws, relevant sector specific regulations, and other laws-like criminal laws or constitutions-that contained provisions regulating market competition. For example, for the United States, we collected every relevant federal law since the passage of the Sherman Act of 1890.

After gathering all of the competition laws, our research teams performed the actual coding of the relevant statutory provisions. To do so, they completed a survey hosted on Qualtrics.com for each law. This survey had 171 entry fields. These fields started with basic identifying information — such as country, law name, year passed, and year enacted-and then proceeded through questions related to substantive statutory provisions. To develop this survey, we built on the efforts of Nicholson (2008) and Hylton \& Deng (2007) and asked questions covering the variables included in their studies. However, we also included several new questions.

Each jurisdiction was assigned to two research team members for independent coding. ${ }^{11}$ Both followed identical procedures. ${ }^{12}$ Importantly, the team members were instructed to code the "competition law regime" in force in any given year, which means that we layered together all the old and new laws in force in any given year to capture the entire set of laws in force at a point in time. A more experienced student was employed as a senior coder whose task was to offer guidance on ambiguous or complicated provisions. We further reviewed this guidance. Once two team members completed a country's coding, the project leader retrieved the data from Qualtrics.com to prepare for a

\footnotetext{
11 While our goal was to double blind code every law, the laws of five jurisdictions were reviewed by just one coder with the assistance of the senior coder due to language restrictions.

12 When proceeding through each section of the survey, the coder was asked to provide yes-or-no responses to a series of questions regarding the existence of specific provisions related to that category. After providing a yesor-no response, the coder copied the actual, relevant statutory text from the laws of the country to write-in fields that followed each question.
} 
discrepancy review. The discrepancy review was then assigned to a third coder, who examined all fields for which the two team members provided differing responses, checked the actual text of the underlying law, and selected the most accurate answer. ${ }^{13}$ The output of the discrepancy review produced a final "consensus" response to every field for every law. Finally, the data was converted to a country-year format to facilitate easy use by researchers.

\section{B. Coverage}

Figure 2 shows the number of jurisdictions and laws covered in the dataset over time. Our research suggests that 135 jurisdictions, including all 34 OECD countries, had a domestic competition law by 2010. Six of those jurisdictions consist of regional organizations, including the EU, which exercise supranational competition jurisdiction over their member states. Of the 135 jurisdictions, we have complete coding of $131-126$ countries and 5 regional organizations. Since many jurisdictions have multiple laws, we coded 700 laws in total. ${ }^{14}$

Figure 3 depicts the six primary categories of variables that we coded for each competition law. First, we coded a series of variables that capture any policy goals embedded in a country's competition laws, including whether the law specifically states goals such as improving consumer welfare, efficiency, or social policy. Second, we coded whether the law notes either an exemption or whether the law is sector specific. For instance, we coded whether the law exempts state owned enterprises or export cartels, and whether the law was specific to industries such as energy, telecom, or transportation. Third, we coded a series of variables that capture the authority granted by the law in the regulation of competition. This includes whether there is a private right of action, the possibility of fines or imprisonment for violation, or extraterritorial application. Fourth, we coded a

\footnotetext{
13 The third coders were directed to provide a comment for each field in which they resolved a discrepancy, explaining the reasoning behind their choice and pointing to the statutory language that supported their decision. As during the first and second coding, the senior coder and we were frequently called upon to assist the third coder performing the discrepancy review and ensure uniformity of interpretation across countries.

14 In two cases - the Dominican Republican and Botswana-the laws were passed prior to 2010, but did not go into effect until after 2010. Although we still coded these laws and include them in the totals reported in Figure 2 , these countries may not be included in various analyses that focus on laws in effect.
} 
number of variables about countries' merger control regimes, such as whether merger notification is mandatory or if efficiency defenses are allowed. Fifth, we coded variables about the regulation of anti-competitive agreements, and, sixth, we coded variables about the regulation of abuse of dominance. For each of the six categories, we attempted to code variables that captured all relevant features of that competition policy. Taken together, these variables provide a detailed picture of competition regimes from countries' first adoption of a competition law through 2010. For scholars interested in using this data as a single variable, we have also created a composite index called the "Competition Law Index" that draws on many of these variables to create a single picture of the regulatory risk posed by countries' competition regimes in each year from 1890 to 2010 (see Bradford \& Chilton 2018).

\section{Limitations}

While the coverage of our dataset far exceeds prior data collection efforts, it is not complete. Thanks to our access to foreign law students, we were able to code laws in Arabic, Armenian, Chinese, Czech, Danish, Dutch, English, French, Finnish, German, Greek, Hebrew, Hungarian, Italian, Japanese, Korean, Slovakian, Slovenian, Spanish, Swedish, Norwegian, Polish, Portuguese, and Russian. But there were three countries and one regional organization where language barriers or lack of access to the legal text have prevented us from completing their coding: ASEAN, Djibouti, Faroe Islands, and Iran. Additionally, there are some countries included in the dataset where we coded some competition laws, but we could not locate all the laws that we believe may exist. Those potentially incomplete countries are: Benin, Ivory Coast, Mali, and Senegal. ${ }^{15}$

An additional potential limitation of our dataset is that we only coded competition statutes and not case law. For those most familiar with American antitrust law, this may seem like an important omission. However, a recent expert survey we conducted suggests there are few countries outside the United States—-primarily common law jurisdictionswhere courts play a significant role in creating new competition law. ${ }^{16}$ One of the questions

\footnotetext{
15 The dataset includes indicator variables for country-years that have either missing or incomplete coding.

16 To better understand the role of courts, agencies, and private parties in the administration of antitrust law, we developed a short survey that we sent to competition law practitioners and scholars around the world. More
} 
in the survey asked: "In practice, do the courts generate new law by changing the scope of the antitrust statutes in [insert country]? Please answer on a scale from 1 (no role) to 5 (extensive role)." Of the 86 countries from which we received survey responses, in only 11 jurisdictions did the respondents say that "courts play an extensive role" i.e., "courts have the power to change the scope of antitrust law and frequently do so." In a further 4 jurisdictions, the experts described the role of courts as "large" i.e., "courts have the power to change the scope of antitrust statues and sometimes do so." Thus, while limited to competition statutes, this dataset captures the vast majority of competition laws in the world and serves as an accurate proxy of the state of competition law in each country.

\section{Stylized Facts About Competition Laws Around the World}

To highlight the richness of this dataset, we will briefly examine the variance around the world in three aspects of competition law: (1) the goals countries stipulate for their competition law; (2) the industries that are exempted from coverage by competition law; and (3) trends in the authority granted to agencies and private parties to enforce competition law.

\section{The Goals of Competition Laws}

The promulgated goals of competition law convey important information about the political, economic, and ideological commitments underlying its enactment. The goals also often reveal what jurisdictions' enforcement priorities are and how they are likely to interpret the substantive commitments embedded in the law. There is considerable variance in these goals across countries. The United States and the European Union are perhaps the most well-known illustration of this point. Historically, the United States' competition law was aimed at curtailing the concentration of economic and political power, reflecting the fear that unfettered economic combination posed a threat to the American economy, democracy, and society (Areeda, Kaplow, \& Edlin 2013, at 35). However, at least since the 1970s, the United States has endorsed the view that

specifically, we sent the survey to our professional network, contacts we had made while collecting the datasets introduced in this paper, attendees of international competition law conferences, and members of the Academic Society of Competition Law (ASCOLA). In total, 166 experts form 86 countries completed our survey. 
competition law should focus on the narrow pursuit of efficiency, which is typically understood as maximization of consumer welfare (Orbacj 2011). The European Union, in contrast, has always employed competition law for a greater variety of goals, including fostering European integration (Fox 1997, at 340), even if consumer welfare remains its primary objective. Moving beyond the United States and the European Union, although some existing studies suggest that countries pursue a wide range of policy goals with their domestic competition laws (Waked 2015), the topic has not been explored with data as comprehensive as in our new dataset.

Panel A of Figure 4 plots the share of jurisdictions with a competition law that have at least one of the eight goals we identified in Figure 3 from 1890 to 2010, and Panel $\mathrm{B}$ plots the share of jurisdictions with a competition law with each of those eight goals in 2010. As Panel A shows, explicit goals have become more common over time. In 1950, just $8 \%$ of jurisdictions with a competition law had one of the eight goals for their competition regimes, but $64 \%$ of jurisdictions with a competition law did by 2010. Panel B shows that although efficiency is considered to be a common goal of competition law, in 2010 it is still explicitly identified by only $31 \%$ of the jurisdictions. Consumer welfare is the most common goal of competition law and found in $40 \%$ of the jurisdictions. Beyond these two goals, the other six goals we coded are less common. These goals range in prevalence from development (in $15 \%$ of jurisdictions) to protecting exports (in $2 \%$ of jurisdictions).

\section{Limits in the Scope of Competition Laws}

Countries commonly carve out certain industries or enterprise types from the scope of their competition law. Our data shows that between 1950 and 2010, roughly twothirds of jurisdictions $(68 \%)$ had at least one exemption in their laws in a given year. ${ }^{17}$ These exemptions are not only prevalent but also significant, both in terms of their economic and political impact. Often, they tell an important story about the political economy underlying a law, indicating which companies or industries enjoy special

\footnotetext{
${ }_{17}$ More specifically, $59 \%$ of jurisdictions had an exemption in $1950,70 \%$ in 1987 , and the number has stayed roughly stable since. For instance, $72 \%$ of jurisdictions had at least one exemption in 2010.
} 
privileges or protection by their governments. It is plausible, even likely, that countries use exemptions as a way to shield certain industries or enterprise types from competition law and hence give them an edge over their competitors in the marketplace. Alternatively, an exemption may reflect the government's view that certain enterprise types should instead be subjected to sector-specific regulations, by which its idiosyncratic characteristics can be better addressed. Our dataset offers the opportunity to systematically examine the types of industries and firms that governments treat differently by exempting them from competition scrutiny, and study how those exemptions differ across time and jurisdiction.

To illustrate the data, Figure 5 graphs the share of jurisdictions with a competition law that either completely or partially exempts different industries. Like Figure 4, Panel A shows the number of jurisdictions with a competition law that partially or completely exempts at least one industry from 1890 to 2010, and Panel B shows the share of jurisdictions that exempt specific industries in 2010. Panel A reveals that roughly half of jurisdictions (49\%) with a competition law include at least one partial or complete industry exemption, and Panel B shows that Agriculture, Transportation, Insurance, Banking, and Fishing are commonly exempted industries in 2010.

\section{Authority to Enforce Competition Law}

In addition to exploring the goals and exemptions listed in competition laws, our data also makes it possible to explore the substantive provisions of regimes around the world. To illustrate the possibilities, we next explore the variance in the enforcement authority provided in competition laws. By authority, we refer to the provisions that determine which parties can challenge alleged anticompetitive behavior and the types of remedies that can be imposed if a violation is found. For instance, is there a private right of action to allow private parties to bring competition cases? Are violations of the law punishable with fines or prison time? Does the law apply extraterritorially?

Figure 6 displays the trends from 1950 to 2010 for each of the six authority variables listed in Figure 3. For each variable, the plots show the absolute number of jurisdictions (displayed on the left-hand y-axis) and the share of jurisdictions (displayed on the right-hand y-axis) with a competition law that have each provision. Unsurprisingly, given the huge increase in the number of jurisdictions with a competition law during this 
period, the absolute number of jurisdictions that have each authority provision in their competition law has increased over time for all six variables. For instance, in 1950 just 6 jurisdictions had a private right of action in their competition law, but by 2010 that number had increased to 71 . What is more revealing, however, is the differences in the share of jurisdictions that have each authority provision. Although the share of jurisdictions that provide for Private Rights of Actions, Divestures, Damages, and Extraterritoriality have all notably increased, the share of jurisdictions with provisions allowing for Fines and Imprisonment for violations of competition laws has not. Instead, although they both were equally common in 1950 (both remedies were found in 90\% of competition laws in 1950) these two remedies have spread in very different ways. More specifically, the share of jurisdictions with Fines has stayed flat (98\% of jurisdictions allow for fines in 2010), but the share of jurisdictions that allow for prison sentences has declined dramatically $(35 \%$ of jurisdictions allowed for prison sentences in 2010). Notably, the availability of prison sentences is a distinctive feature of American antitrust law, and our dataset reveals that this provision has not diffused around the world.

\section{Comparative Competition Enforcement Dataset}

Although there are many more trends that can be explored in the Comparative Competition Law Dataset, we now turn to introducing our second dataset: the Comparative Competition Enforcement Dataset. First, we again begin by explaining the process we used to collect the data. Second, we summarize the countries and years covered by the dataset, as well as the variables it contains. Third, we discuss limitations of the dataset. Finally, we use the data to document three stylized facts about the enforcement of competition law around the world.

\section{A. Collection Process}

The process of collecting the enforcement data entailed multiple steps. We first determined the precise variables that we would use to capture the agencies' enforcement resources and activity. This determination was made based on a broad yet preliminary 
review of the extent and the type of data that agencies make available. ${ }^{18}$ After determining the nature and scope of the data we wanted to collect, we trained and managed over 40 law students from Columbia Law School and the University of Chicago Law School to carry out the data collection process over a period of five years. As with the team we assembled to code the Comparative Competition Law Dataset, we recruited students from a broad range of countries with relevant language skills and legal expertise.

We then identified jurisdictions with competition agencies in place between 1990 and 2010. For the agencies we identified, our research team first reviewed all publicly available information on enforcement resources and activities. This entailed conducting a detailed review of competition agency websites and annual reports, databases such as GCR 19 or "Getting the Deal Through,"20 and studies and research reports by organizations such as the OECD or UNCTAD. When these diverse sources provided conflicting data, we more heavily weighted data provided in the agencies' annual reports. Most agencies made some information on their resources or activities publicly available, but the extent varied from very limited in the case of many non-OECD countries to quite comprehensive in the case of a subset of established competition law jurisdictions.

After this review of publicly available information, we drafted questionnaires that were individually tailored for each agency. That is, for any given agency, we developed a questionnaire that focused only on information that we had not found in the public domain or where the publicly available information was conflicting. We first contacted the agencies by email in English. If this did not elicit a response, the correspondence took place in Spanish, French, Russian, and Arabic, as needed. We typically contacted the agency following an introduction by a personal contact within the agency, international competition law bar, international legal academia, or an organization such as the UNCTAD or ICN. These introductions, together with the contacts of foreign students at Columbia and Chicago back in their home jurisdictions, were crucial in persuading the agencies to share the data with us. To obtain the needed data for Australia, India, and the

\footnotetext{
18 Special thanks to Keira Campbell who was central in helping us determine the particular variables that were most important and at the same time feasible to collect.

${ }^{19}$ Global Competition Review, http://globalcompetitionreview.com/ (last visited March 7, 2018).

${ }^{20}$ GetTing THE DeaL Through, https://gettingthedealthrough.com/ (last visited March 7, 2018).
} 
United Kingdom, we relied on formal Freedom of Information Act (FOIA) requests, while continuing to benefit from proactive cooperation by government officials.

Most of the agencies we contacted responded with additional information-some responded within day, while others responded after several requests over multiple years. Where possible, we attempted to further verify the data provided to us by agencies through comparison to our public sources. For example, we used the data we separately assembled on competition statutes to confirm whether missing enforcement data reflected a lack of authority to engage in certain enforcement activity or simple unavailability of data. For some jurisdictions, we also conducted extensive review of individual enforcement decisions to assemble additional data that the agencies did not otherwise have readily available. ${ }^{21}$ After these steps, research assistants entered the responses to the questions into the master dataset. As a final step, one of us further verified the entries into the master dataset as part of a final review of the data.

\section{B. Coverage}

We attempted to collect data on all 116 jurisdictions that our research identified as having established a dedicated competition agency by 2010. In the end, we managed to obtain some data-whether on resources or activity or both-from 112 agencies representing 100 jurisdictions. ${ }^{22}$ While 103 individual agencies cooperated with us, we relied solely on publicly available information for the remaining 9 agencies, as we could not elicit a response from them. In 10 of the countries in our dataset, enforcement has been carried out by more than one agency. ${ }^{23}$ For these multi-agency countries, we have

\footnotetext{
21 This included some developing jurisdictions such as Venezuela, but it also included some established jurisdictions like Austria, the European Union, and South Africa.

22 In addition to the countries with competition agencies in our dataset, we collected data for three regional organizations - the Caribbean Community (CARICOM), the Common Market for Eastern and Southern Africa (COMESA), and the European Union (EU) — that exercise supranational competition jurisdiction over several countries. It is worth noting that there are at least five other regional organizations that have some degree of supranational competition policy: Andean Community (CAN), East African Community (EAC), Economic Community of West African States (ECOWAS), European Free Trade Area (EFTA), and West African Economic and Monetary Union (WAEMU). However, the agencies for EAC and ECOWAS were established after 2010 (the cut off for our data collection efforts), and we were unable to obtain data from the CAN, the EFTA, and the WAEMU.

23 The countries with more than one agency in our dataset are: Austria, Brazil, Chile, China, France, Luxembourg, South Africa, Spain, United Kingdom, and the United States.
} 
recorded the resources and activities for each agency separately but combined them in the analysis based on our case-by-case review of their (at times complementary and at other times overlapping) enforcement powers. ${ }^{24}$

We attempted to gather data for the years 1990, 1995, and 2000-2010 (although we accepted whatever data agencies gave us, even if it was from, for example, 1994 or 1998). We decided to try to collect data starting in 1990 for two reasons. First, the early 1990s marked the beginning of a new era in competition enforcement when competition regimes started to proliferate dramatically, including outside the OECD countries. Second, our preliminary inquiries suggested that only a limited number of agencies could provide any reliable data for any years prior to 1990. For many agencies, the data for 1990 or 1995 was also sparsely available. If the agency was established after 1990, the first year of the agency's operation marks the first year of data gathering for that country. For instance, for Albania, which established its agency in 2004, we have data for 2004-2010.

Figure 7 illustrates the availability of data over the relevant years. For the year 1990, we managed to obtain some data for 15 jurisdictions. We obtained data for an increasing number of jurisdictions for the subsequent years: 38 jurisdictions provided some data for 1995, 63 for 2000, 81 for 2005, and 97 for 2010. It is also worth noting that Figure 7 reports the number of jurisdictions that provided some data in a given year and not the number of jurisdictions that provided complete data. Some jurisdictions were able to provide some information for a given year-for instance, their competition agency's budget - but were not able to provide other information we requested — for instance, the number of dominance investigations completed with a remedy.

Figure 8 depicts the primary 17 variables we collected that measure either the resources the jurisdictions dedicated to competition law enforcement or the actual enforcement activities. ${ }^{25}$ To measure the enforcement resources, we assembled data on the

\footnotetext{
24 We learned that many countries have gone through several changes in their competition institutions over the years. In our dataset, we record the first year when a dedicated competition agency was established or when an established agency first gained powers to enforce competition laws. Thus, a country could have had some competition enforcement take place prior to establishing a dedicated competition agency if, for instance, another Ministry (often trade or some other ministry responsible for commercial affairs) engaged in some prior enforcement activity.

25 Although we tried to collect the same 17 variables for each jurisdiction for each relevant year, not all agencies provided all variables for all relevant years. In addition, some agencies provided additional or slight variations of
} 
competition agency budgets and the number of agency staff members. To measure enforcement activity, we gathered data on the three main anticompetitive activities that competition agencies regulate: Merger Control, Anticompetitive Agreements, and Abuse of Dominance. For Merger Control, we collected annual data on the number of mergers notified to the agency, the number of mergers that proceeded to second stage review, the number of mergers resolved with conditional clearance, ${ }^{26}$ the number mergers blocked, and the number of mergers that were withdrawn. For Anticompetitive Agreements, we collected annual data on the number of cartel investigations an agency opened, the average duration of its cartel investigations, the number of cartel investigations it closed with a fine or other remedy, and the total/average amount of cartel fines it imposed. For countries that provide for criminal remedies, we further collected annual data on the number of cases where criminal remedies were sought and the number of cases where criminal remedies were imposed. Finally, for Abuse of Dominance, we compiled annual data on the number of dominance investigations an agency opened, the average duration of its dominance investigations, and the number of dominance investigations it closed with a fine or other remedy.

\section{Limitations}

Like with the Comparative Competition Laws Dataset, our enforcement data has limitations. First, as discussed in Part 4.2, despite trying to thoroughly comb public records and directly communicate with enforcement agencies, there are several jurisdictions from which we did not receive data, and other jurisdictions where the data we received was incomplete. Second, this dataset only captures public enforcement, which leaves aside any private enforcement activity. This omission again seems most significant for the United States. This is confirmed by our expert survey, in which we also inquired about the

these standard variables if our requested metrics were not available. Thus, in the end, our dataset consists of 41 additional variables that are available for a limited number of jurisdictions.

26 By mergers resolved with conditional clearance, we refer to mergers that are approved subject to commitments or conditions, such as behavioral or structural remedies. In some jurisdictions, these conditional clearances are known as negotiated settlements. It is also worth noting that the breakdown of the variables we collect for merger control is similar to Seldeslachts et al. (2009). 
significance of the private enforcement in each jurisdiction's competition law regime. ${ }^{27}$ The survey specifically asked: "In practice, how important a role do private parties play in enforcing antitrust law in [insert country]? Please answer on a scale from 1 (no role) to 5 (extensive role)." In the survey responses, the United States was the only country to receive a score of $5 .{ }^{28}$ Thus, while the data we collected is limited to public enforcement, we believe it captures the vast majority of competition law enforcement activity in the world. Third, our data does not capture broader institutional features of competition law regimes. Although we recognize that institutional arrangements-including governance structures and management culture - can reveal important aspects of the actual operation of the law and influence the overall de facto stringency of the competition law regime, these features were not included as part of this data collection effort.

\section{Stylized Facts About Competition Enforcement Around the World}

To demonstrate some of the features of these data, we now turn to documenting a few stylized facts about enforcement activity. In what follows, we introduce the data by reporting raw numbers on enforcement activities and resources. Simply looking at raw numbers, however, may mask the actual enforcement of competition law across jurisdictions. For instance, meaningful comparisons of budgets need to account for the size of countries' economies. It may also be a mistake to conclude that the number of investigations is a reliable proxy for the strength of an antitrust regime. Some regimes may achieve deterrence without having to open investigations, while other regimes may only investigate a fraction of actual violations. That said, to illustrate these data, we examine: (1) the extensive use of competition investigations by Russia and other former members of the USSR; (2) the countries that have devoted the most resources to competition enforcement and had the most investigations; and (3) the merger review activity of the United States and the European Union.

\footnotetext{
${ }^{27}$ For more information on the survey, see supra note 16.

28 The experts in just four further jurisdictions responded that "private parties play a large role." These jurisdictions were Germany, Jordan, Slovenia, and Spain. In the other 64 countries we surveyed, the experts described the role of the private antitrust enforcement as "insignificant," "limited," or "inexistent" in their jurisdiction.
} 


\section{Competition Law Enforcement by Russia and Former Members of the USSR}

Perhaps the most striking trend in the enforcement data we collected is the staggering number of investigations conducted by Russia and the members (and associate members) of the Commonwealth of Independent States ("CIS"). ${ }^{29}$ Although the former members of the USSR that never joined the CIS—Estonia, Latvia, and Lithuania—have enforcement patterns that are similar to the median agencies in the dataset, the members of the CIS are dramatic outliers. To illustrate this, Figure 9 presents data on competition enforcement resources and activities while breaking out CIS members from the other countries in the dataset.

Russia is the most important part of the story shown in Figure 9. Russia's competition law enforcement activities bear little resemblance to the rest of the world. For example, Russia had an arresting 89\% share of the world's total Abuse of Dominance investigations closed with remedy in 2010. While the United States closed 2 dominance investigations with remedies and the European Commission closed 4 in 2010, Russia closed 1,453 dominance investigations with remedies that year. Russia similarly remains an outlier when compared to other emerging economies: Brazil closed 1 dominance investigation with a remedy that year while India, China, and South Africa closed 0, 0, and 2 , respectively. While abuse of dominance investigations is the area where Russia is the most notable outlier, Russia is also active in other areas of enforcement. For instance, it prohibited or conditionally cleared 83 mergers in 2010 , which represents $26 \%$ of all merger enforcement action in that category across the world that year. But even that figure pales in comparison with the 578 mergers that Russia reported as prohibited in 2009 (for comparison, the rest of the world prohibited 224 mergers in 2009).

In our follow-up research and conversations, the Russian agency offered several explanations for their distinctive enforcement patterns. First, Russia relies on competition law as a tool to pursue price regulation, which increases the number of investigations. Second, the agency also described many Russian product markets as being highly

\footnotetext{
29 The CIS formed when the Soviet Union dissolved in 1991. At its conception, the CIS consisted of ten former Soviet Republics: Armenia, Belarus, Kazakhstan, Kyrgyzstan, Moldova, Russia, Tajikistan, Turkmenistan, Ukraine, and Uzbekistan.
} 
concentrated, explaining the need for frequent interventions. ${ }^{30}$ Finally, the agency confirmed that it deals with many small cases as opposed to focusing on large ones.

However, these official explanations do not tell the entire story. First, although Russia may be using competition law to target highly concentrated domestic markets and pursuing small cases, its enforcement efforts also target large international firms. Just last year, Russia fined Google $\$ 6.75$ million for abusing its dominant position by forcing retailers to install apps on cell phones using Android software (Grove 2016). Russia's competition agency is also investigating Apple Inc. in a price fixing case (Perlman 2016). Second, the regulation and categorization of various anticompetitive activities in Russian law and agency reporting is inconsistent with international norms.${ }^{31}$ For example, the high cartel activity numbers likely include cases that are simply horizontal (non-cartel) agreements between competitors or even cases that others would characterize as vertical agreements. $^{32}$ The Russian agency also uses competition law to curb inflation and to control prices. ${ }^{33}$ The Russian concept of abusive behavior also includes many practices that do not fit under any standard theory of competitive harm, like initiating abuse of dominance investigations for firms accused of "infring[ing on] rights/interests of third parties" (Khokhlov 2014, at 34). Third, experts have described Russian competition law enforcement as "relentless" and "excessive," and noted Russia's tendency to pursue objectives unrelated to competition (Girgenson \& Numerova 2012). In fact, Girgenson \& Numerova (2012) argue that the general public is very keen to see the agency go after "excessive" prices and supports the use of competition law as an instrument for price control. This is particularly true against major Russian industrial players, like Gazprom and Rosnef, that operate in politically sensitive industries like agriculture and energy.

\footnotetext{
${ }^{30}$ Russia ranked $88^{\text {th }}$ out of 139 countries for "Extent of Market Dominance" and $115^{\text {th }}$ for "Intensity of Local Competition" in the World Economic Forum Competitiveness Report for 2010-2011, (lower rankings are associated with higher levels of competition, e.g., Germany ranks $1^{\text {st }}$ for "Extent of Market Dominance"). See http://www3.weforum.org/docs/WEF_GlobalCompetitivenessReport_2010-11.pdf (last visited March 22, 2018).

${ }^{31}$ New Indicators of Competition Law and Policy in 2013 for OECD and Non-OECD Countries, OECD Economics Department Working Papers No. 1104 ECO/WKP (2013), at 21.

32 As of 2012, Russia has made a distinction between cartels and other restrictive agreements, narrowing the scope of what constitutes a "cartel" (Khokhlov 2014, at 32-33).

33 OECD Economic Surveys: Russian Federation 2011 (Dec 2011).
} 
Kazakhstan and Ukraine also have unusually high enforcement levels. In 2010, Kazakhstan resolved 49 dominance investigations with remedy, which is over eight times more than the United States and the European Union combined. For Ukraine, we were not able to obtain data for dominance investigations closed with remedy. But our data shows that Ukraine alone opened 621 dominance investigations in 2010, following 614 and 480 in 2009 and 2008, respectively. The numbers are high for cartel investigations as well: Ukraine initiated 272 cartel investigations in 2010 while Kazakhstan initiated 39. Although we do not have data on cartel investigations closed in Ukraine, Kazakhstan closed 34 cartel investigations with remedy in 2010. Like in Russia, many of the cases may be directed at smaller companies. The Kazak antimonopoly legislation, for instance, allows the agency to initiate dominance investigations against companies with market share of less than $35 \% .^{34}$

\section{Jurisdictions with the Most Enforcement Resources \& Activities}

Although the huge number of competition investigations initiated by Russia and other members of the CIS is perhaps the most surprising trend in the enforcement data, there are also a number of small markets that have been unexpectedly active players in competition law enforcement. To illustrate this, Figure 10 presents the trends for the five countries with the most enforcement resources and activities based on their 2010 data.

The countries that were best resourced are not particularly surprising-instead, staff sizes and budgets appear to correlate strongly with market size. With respect to staff size, the United States had the greatest number of staff in 2010 with a combined 1,320 people working in antitrust enforcement at Department of Justice and Federal Trade Commission. Japan had the second highest staff numbers, with 791 people working on competition law in 2010, followed by the European Union, Brazil, and Canada with 590, 425, and 420 staffers working in each agency, respectively. ${ }^{35}$ With respect to budget, the

\footnotetext{
${ }^{34}$ Law No. 144 of the Republic of Kazakhstan (19 Jan. 2001) Concerning Competition and Restriction of Monopoly, Art. 14, 16; see also Commercial Code of the Republic of Kazakhstan No. 375 (29 Oct. 2015) (the aggregate market share threshold for anti-competitive concerted practice increased from $15 \%$ to $35 \%$, liberalizing the regulation of smaller market share holding entities).

35 The median agency had 62 people working at it in 2000 and 56 in 2010.
} 
United States also dedicated the most resources to competition law enforcement. The combined Department of Justice and Federal Trade Commission budget for competition enforcement was 288 million USD in 2010. China established its three competition agencies in 2008 and immediately vested them with significant budgets. In fact, in 2010, the combined budget of Chinese agencies was 220 million USD, which was the second highest budget held by any jurisdiction. Following the United States and China, the next highest budgetary resources in 2010 were found in Japan (96 million USD), United Kingdom (73 million USD), and Australia (59 million USD). These can be compared to a median agency budget of 3.3 million USD in 2010.

Figure 10 also presents trends for the five countries that engaged in the highest levels of six types of enforcement activities in 2010. Many of the countries that were most active across these different areas of enforcement are large, well-resourced, and established jurisdictions, such as the United States, the European Union, Brazil, Germany, and South Korea. These are regional leaders that undertake cases that often have an impact far beyond their own jurisdiction. However, among the top enforcers we also see some more surprising, small agencies, such as Bulgaria, Finland, Iceland, Ireland, and Namibia. There can be idiosyncratic reasons for some of these small countries' high activity levels. However, one likely reason is that these are often relatively small (and hence more concentrated) markets or geographically more isolated markets that can rely less on regulators in large and well-connected economies doing the enforcement for them. Competition enforcement may hence be particularly important for these small countries dominated by a few large companies that control a substantial part of the economy in question (Gal 2003). In other cases, these high activity levels may reflect particular features of a country's law. For instance, the reason Ireland reports such high number of abuse of dominance investigations is that the Irish authority reviews every complaint and counts that as a new investigation even if the investigation is promptly closed in the absence of any anti-competitive concerns.

3. Comparing Merger Review in the United States and the European Union

The United States and the European Union garner the most attention in conversations about international competition law (Fox 2010). Many comparative law 
papers, lectures, courses, and conferences are focused on these two jurisdictions alone. ${ }^{36}$ Although one goal of our data collection efforts is to make it possible to look beyond these two traditional competition powers and examine how competition law has gone global, our data can also be used to exam trends in established jurisdictions like the United States and the European Union. To illustrate this point, we conclude by examining an area that has been the subject of a great deal of debate over the last several decades: merger review. ${ }^{37}$

While the United States has exercised control over mergers since 1914 and adopted mandatory merger notification in 1976, the European Union only began to exercise authority to review mergers in 1990. Figure 11 illustrates several key trends in merger review in the twenty years following the European Union's adoption of a merger review regime. As the first panel shows, from 1990 to 2010, the United States systematically received more merger notifications than the European Union. During this period, the United States received 2,319 notifications per year on average. In contrast, the European Union received 217 notifications per year on average. The greater overall United States activity in merger enforcement is likely a function of both deal flow and notification thresholds. Not only is there typically greater M\&A activity in the United States, the baseline for merger review activity-the notification thresholds-differs and hence catches somewhat different deals, at least at the margin. ${ }^{38}$

However, Figure 11 also shows that the picture looks different when comparing the percentage of the notified deals that are subjected to an in-depth review, a conditional clearance, or an actual prohibition. On average, 5\% of notifications lead to a second request investigation in the European Union while only 3\% are investigated in depth in the United States. ${ }^{39}$ Similarly, on average, the European Union conditionally clears $6 \%$ of

\footnotetext{
36 A notable exception is the scholarly attention China and a few other emerging competition jurisdictions have received. See, e.g., Gerber 2010; Hylton \& Deng 2007; Williams 2005.

${ }^{37}$ It is important to note that European Union Member States also play an important role in the enforcement of competition law in Europe (e.g. Barros et al. 2013), and looking at European Union Commission activity alone may undercount competition enforcement taking place across the European Union as a whole.

38 The United States bases its threshold on merging parties' assets while the European Union uses revenue as the decisive factor, making the overall numbers difficult to compare (Gidley \& Paul 2009).

${ }^{39} \mathrm{It}$ is worth noting that second stage investigations contain some important differences across jurisdictions. For example, in the US, conditional clearances only take place after the second request is issued whereas in the European Union the Commission can also clear a merger conditionally in Phase I.
} 
the mergers notified while this figure is $1 \%$ in the United States. In terms of prohibitions, the European Union averages at $0.5 \%$ of mergers notified to it while the United States' average prohibition rate is $0.3 \%$ a year.

Given the European Union's reputation as the world's most stringent competition regime (Bradford 2013), the European Union's higher relative challenge rate is not a surprise. Conventionally, the European Union is portrayed as being less trusting of the self-correcting forces of the markets and more confident in the ability of the regulators to improve market outcomes. The European Union is also viewed as being more hostile to dominant companies, and hence more inclined to restrict mergers that may lead to greater dominance. While both jurisdictions recognize that mergers can lead to efficiencies and are seen as often agreeing on the competitive effects of horizontal mergers, the European Union is more inclined to challenge vertical and conglomerate mergers, which the United States presumes as efficient except in rare instances.

Interestingly, this transatlantic divergence in challenge rates diminished after 2000. There could be several explanations for this. For one, in 2002 the United States and the European Union agencies signed the "Best Practices" agreement, which sets forth how the two authorities can work together to promote cooperation and convergence in their merger review processes. ${ }^{40}$ Additionally, 2002 and 2004 are considered watershed moments in European merger control. In 2002, the European courts departed from their traditional, restrained judicial review and, in an embarrassing rebuke to the Commission, annulled three Commission merger decisions within a span of five months (Overd 2002). ${ }_{4}^{41}$ The Commission responded to these setbacks by radically reforming the substance and procedure it uses for merger review (Gerber 2003; Vranas-Iveris 2008; Baskoy 2008). This process culminated in the adoption of a new merger regulation in $2004 .{ }^{42}$ These events may have contributed to a more restrained review in the second decade even though the conditional clearances remained relatively high. Of course, the European Union's

\footnotetext{
40 US-EU Merger Working Group Press Release IP/02/1591, Best Practices on Cooperation in Merger Investigations (Oct. 30, 2002).

${ }^{41}$ Case T-342/99, Airtours v. Commission, 2002 E.C.R. II-02585; Case C-440/07 P Commission v. Schneider Electric SA, 2009 E.C.R. I-00073; Case COMP/M.2416, Tetra Laval/Sidel, 2004 O.J. (L 43) 13.

42 Council Regulation (EC) No 139/2004 of 20 January 2004 on the control of concentrations between undertakings (The EC Merger Regulation) 2004 O.J. (L 24) 1.
} 
challenge rate has steadily declined over the course of the two decades and it would be difficult to estimate how much can be attributed to any such external shocks as opposed to a more gradual shift in the European Union's policy over time.

\section{Conclusion}

This paper introduced two new datasets on competition law around the world: the Comparative Competition Law Dataset and the Comparative Competition Enforcement Dataset. These datasets are freely available for download and formatted for easy use. We envision that these datasets can be put to a wide range of uses. For one, they can be used to study the diffusion of competition law-or specific components of competition lawacross countries (e.g. the data we collected can be used as a dependent variable). Additionally, the data can be used to study the effect of competition policy on things like economic growth and development (e.g. the data we collected can be used as an independent variable). Moreover, the data can be used to account for competition policy and market regulation by scholars studying a range of other topics (e.g. the data can be used as a control variable). Finally, these datasets may be of interest to scholars doing non-

quantitative work because they make it possible to quickly look up the provisions of (almost) every country's competition regime. Taken together, we hope these datasets will advance the study of competition law specifically and the empirical study of comparative law more generally. 


\section{REFERENCES}

Aghion, Philippe, Nick Bloom, Richard Blundell, Rachel Griffith, and Peter Howitt. 2005. "Competition and Innovation: An Inverted-U Relationship." Quarterly Journal of Economics 120(2): 701-728.

Areeda, Phillip, Louis Kaplow, and Aaron Edlin. 2013. Antitrust Analysis: Problems, Text, and Cases. $7^{\text {th }}$ Edition. Boston, MA: Little, Brown and Company.

Barros, Pedro P., Joseph A. Clougherty, and Jo Seldeslachts. 2013. "Europeanization of EU Member-State Competition Policy: The Commission's Leadership Role." International Review of Law and Economics 34: 41-51.

Baskoy, Tuna. 2008. The Political Economy of European Union Competition Policy: a Case Study of the Telecommunications Industry. New York, NY: Routledge.

Bradford, Anu. 2013. “The Brussels Effect.” Northwestern University Law Review 107(1): 167.

Bradford, Anu, and Adam Chilton. 2018. "Competition Law Around the World from 1889 to 2010: The Competition Law Index." Journal of Competition Law \& Economics (forthcoming).

Chang, Yun-Chien, Nuno Garoupa, and Martin Wells. 2018. "Redrawing the Legal Family Tree: An Empirical Comparative Study of 108 Property Doctrines in 154 Jurisdictions." Working Paper.

Clougherty, Joseph A. 2010. "Competition Policy Trends and Economic Growth: CrossNational Empirical Evidence." International Journal of the Economics of Business 17(1): 111-127.

Elkins, Zachary, Tom Ginsburg, and James Melton. The Endurance of National Constitutions. New York, NY: Cambridge University Press.

Fox, Eleanor. 1997. US and EU competition law: A Comparison, in GLOBAL COMPETITION POLICY (E. Graham and J. David, eds).

Fox, Eleanor and Daniel Crane. 2010. Global Issues in Antitrust and Competition Law. Saint Paul, MN: West Academic Press.

Gal, Michal. 2003. Competition Policy for Small Market Economies. Cambridge, MA: Harvard University Press.

Gerber, David. 2010. Global Competition: Law, Markets and Globalization. Oxford, UK: Oxford University Press. 
Gerber, David. 2004. Courts as Economic Experts in European Merger Law, in Annual Proceedings of the Fordham Corporate Law Institute: International Antitrust Law and Policy (Barry E. Hawk, ed).

Gidley, J. Mark, and George L. Paul. 2009. Worldwide Merger Notification Requirements. Austin, TX: Kluwer Law International.

Girgenson, Ianis, and Anna Numerova. 2012. "Reform of Russian Competition Law: It's a Long Way from Brussels to Moscow." Journal of European Competition Law \& Practice 3(3): 293-299.

Grove, Thomas. 2016. "Russia Fines Google $\$ 6.75$ Million in Antitrust Case." Wall Street Journal (Aug. 11, 2016), http://www.wsj.com/articles/russia-fines-google-6-75million-in-antitrust-case-1470920410.

Gutmann, Jerg, and Stefan Voigt. 2014. "Lending a Hand to the Invisible Hand? Assessing the Effects of Newly Enacted Competition Laws." Unpublished manuscript. University of Hamburg, Institute of Law and Economics, February, https://papers.ssrn.com/sol3/papers.cfm?abstract-id=2392780.

Hylton, Keith N., and Fei Deng. 2007. "Antitrust Around the World: An Empirical Analysis of the Scope of Competition Methods and Their Effects." Antitrust Law Journal 74(2): 271-341.

Law, David, and Mila Versteeg. 2011. "The Evolution and Ideology of Global Constitutionalism." California Law Review 99(5): 1163-1254.

Kee, Hiau Looi, and Bernard Hoekman. 2007. "Imports, Entry and Competition Law as Market Disciplines.” European Economic Revien 51(4): 831-58.

Khokhlov, Evgeny. 2014. "The Current State of Russian Competition Law in the Context of its Harmonisation with EU Law." Journal of European Competition Law \& Practice 5(1): 32-38.

Michael Krakowski, Competition Policy Works: The Effect of Competition Policy on the Intensity of Competition - An International Cross-Country Comparison, HWWA Discussion Paper 332 (Sept. 2005).

Ma, Tay-Cheng. 2011. "The Effect of Competition Law Enforcement on Economic Growth." Journal of Competition Law and Economics 7(2):301-334.

McCloughan, Patrick, Sean Lyons, and William Batt. 2007. The Effectiveness of Competition Policy and the Price-Cost Margin: Evidence from Panel Data, ECONOMIC AND SOCIAL RESEARCh Institute Working PAPER No. 209. 
Nicholson, Michael W. 2008. "An Antitrust Law Index for Empirical Analysis of International Competition Policy." Journal of Competition Law and Economics 4(4):1009-1029.

Orbacj, Barak. 2011. "The Antitrust Consumer Welfare Paradox." Journal of Competition Law and Economics 7(1): 133-164.

Overd, Alan. 2002. "After the Airtours Appeal." European Competition Law Review 23(8): 375- 377.

Perlman, Matthew. 2016. "Russia Opens IPhone Price-Fixing Investigation." LAw360 (Aug. 8, 2016), http://www.law360.com/articles/825861/russia-opens-iphoneprice-fixing-investigation.

Petersen, Niels. 2013. "Antitrust Law and The Promotion of Democracy and Economic Growth." Journal of Competition Law and Economics 9(3): 593-636.

Sama, Danilo. 2013. "The Effectiveness of Competition Policy: An Economic Assessment in Developed and Developing Countries (2013)." Working Paper, available at https://ssrn.com/abstract=2425335 (last visited Jan. 2, 2017).

Seldeslachts, Jo, Joseph A. Clougherty, and Pedro Pita Barros. 2009. "Settle for Now but Block for Tomorrow: The Deterrence Effects of Merger Policy Tools." Journal of Law and Economics 52(3): 607-634.

Voigt, Stefan. 2009. "The Effects of Competition Policy on Development-CrossCountry Evidence Using Four New Indicators.” Journal of Development Studies 45(8): 1225-1248.

Vranas-Liveris, Elena. 2008. "Impala v. Commission: Changing the Tune of European Competition Law." Chicago Kent Law Review 83(3): 1497-1521.

Waked, Dina I. 2010. "Antitrust Enforcement in Developing Countries: Reasons for Enforcement and Non-Enforcement Using Resource-Based Evidence." Unpublished manuscript. Harvard Law School, July, http://ssrn.com/abstract=1638874.

Waked, Dina I. 2010. "Antitrust Goals in Developing Countries: Policy Alternatives and Normative Choices." Seattle University Law Review 38(3): 945-1006.

Williams, Mark. 2005. Competition Policy and Law in China, Hong Kong and Taiwan. Cambridge, UK: Cambridge University Press. 


\section{FIGURES}

Figure 1: Adoption of First Competition Law

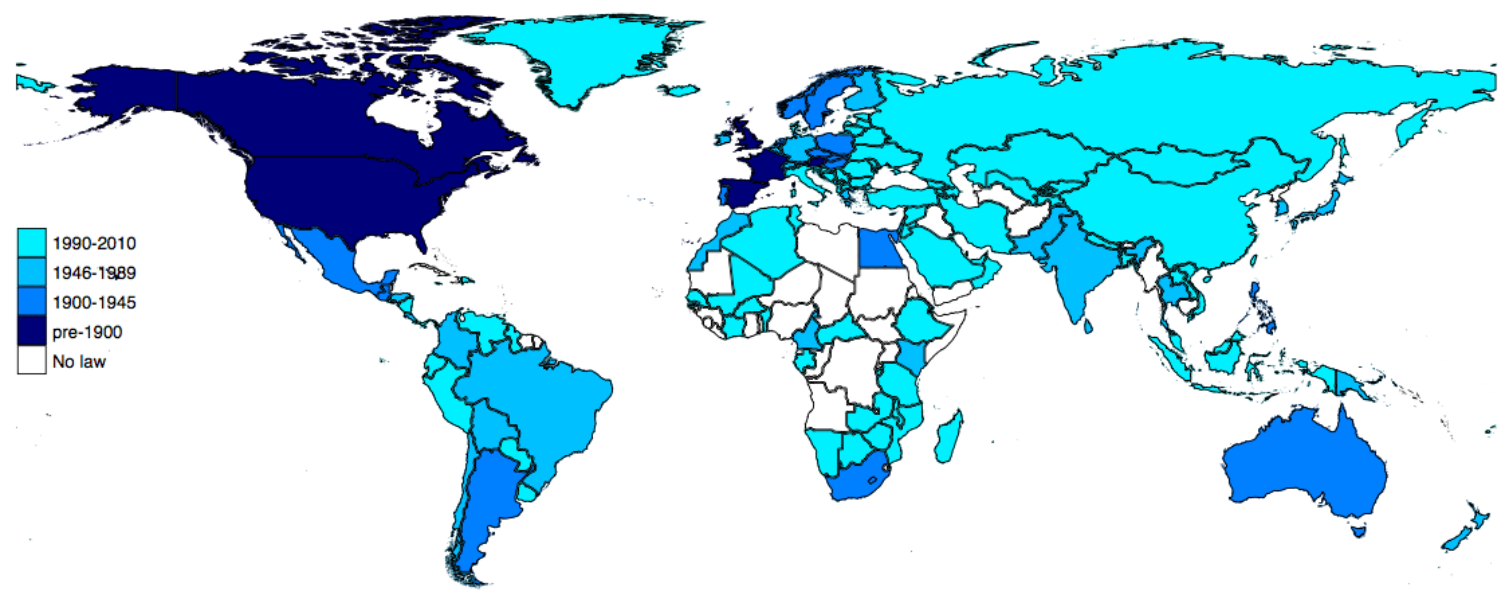


Figure 2: Comparative Competition Law Dataset - \# of Jurisdictions \& Laws
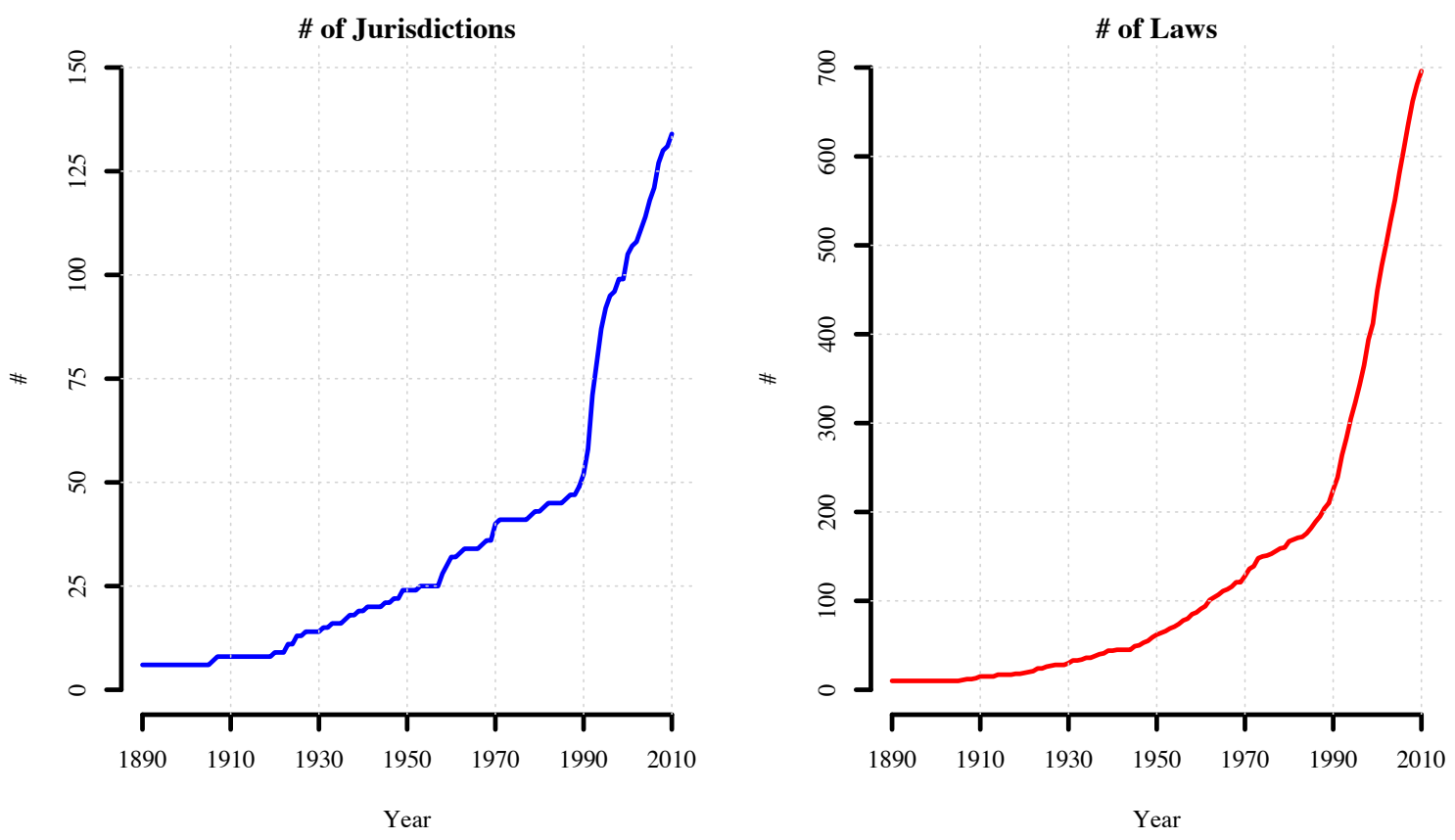
Figure 3: Comparative Competition Law Dataset - Main Variables

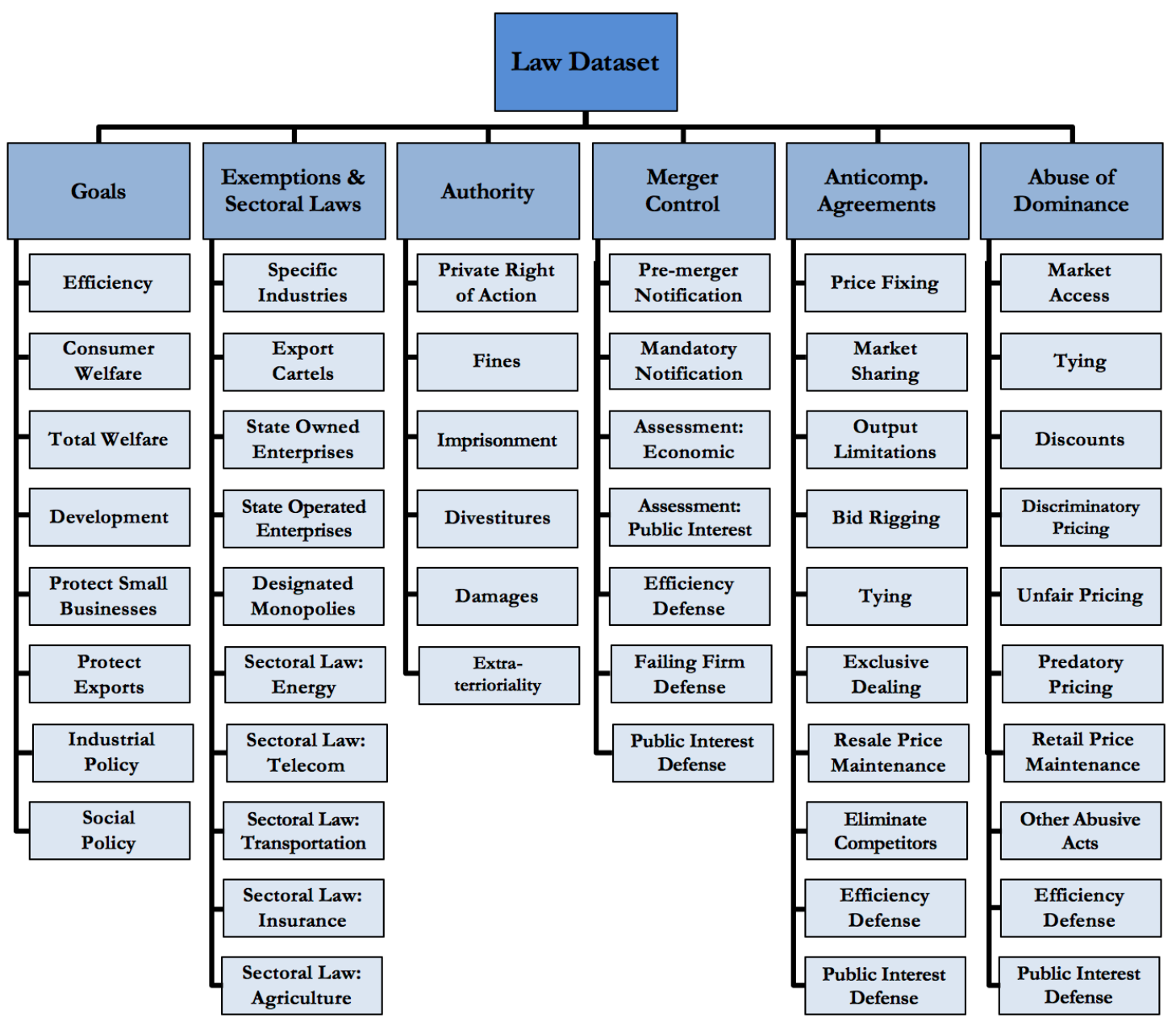


Figure 4: Comparative Competition Law Dataset - Explicit Goals

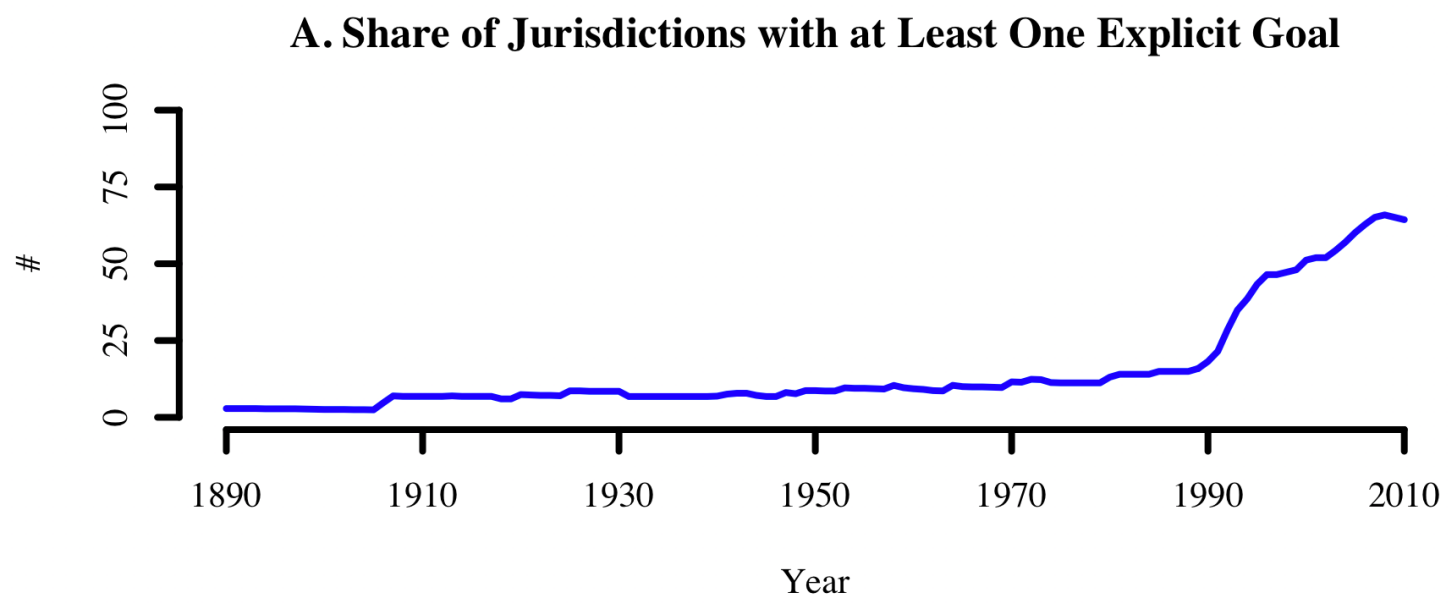

B. Share of Jurisdictions with Select Explicit Goals in 2010

Efficiency

Consumer Welfare

Total Welfare

Development

Protect Small Businesses

Protect Exports

Industrial Policy

Social Policy

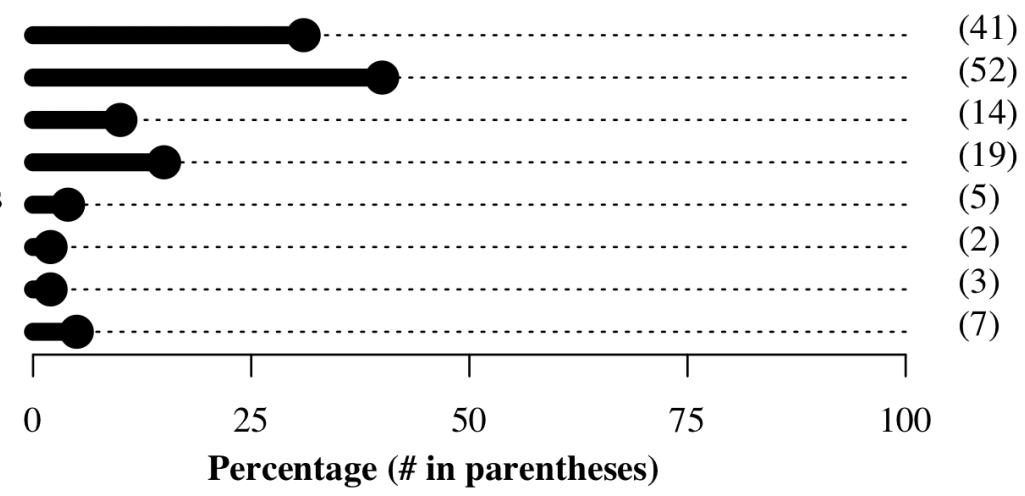


Figure 5: Comparative Competition Law Dataset - Exempted Industries

A. Share of Jurisdictions that Exempt at Least One Industry

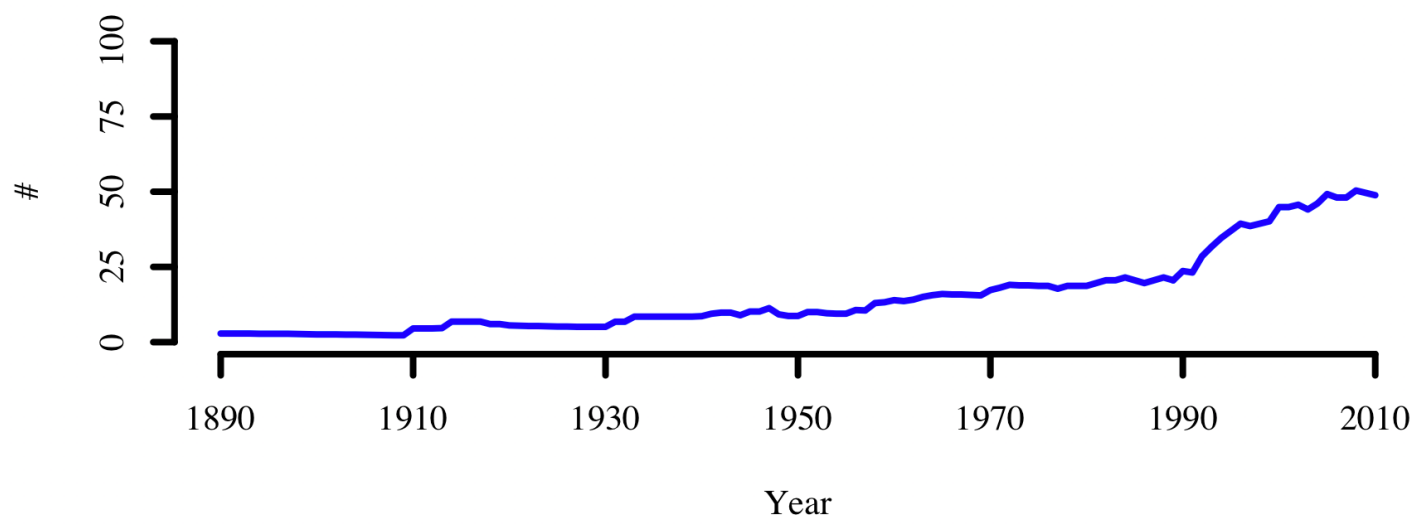

B. Share of Jurisdictions that Exempt Select Industries in 2010

Agriculture

Transportation

Insurance

Banking/Securities

Fishing

Energy

Postal Services

Military

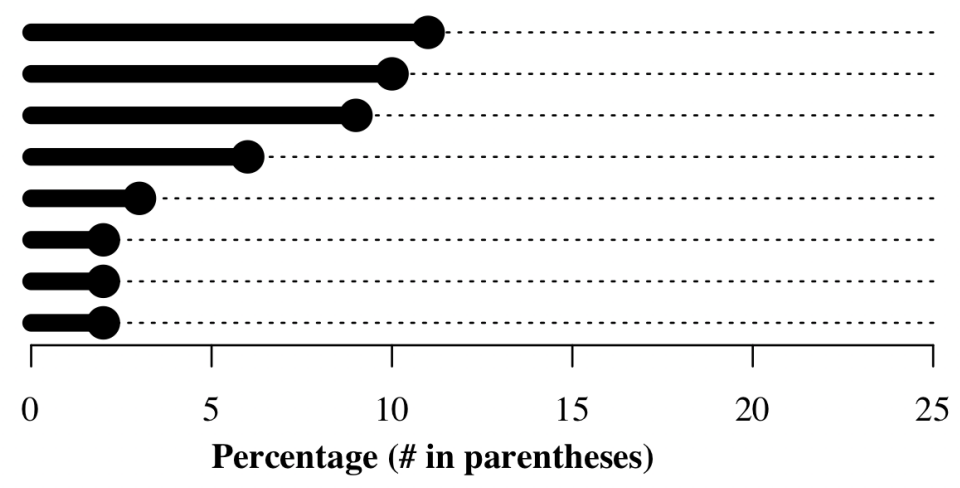


Figure 6: Comparative Competition Law Dataset - Authority Provisions

Private Right of Action

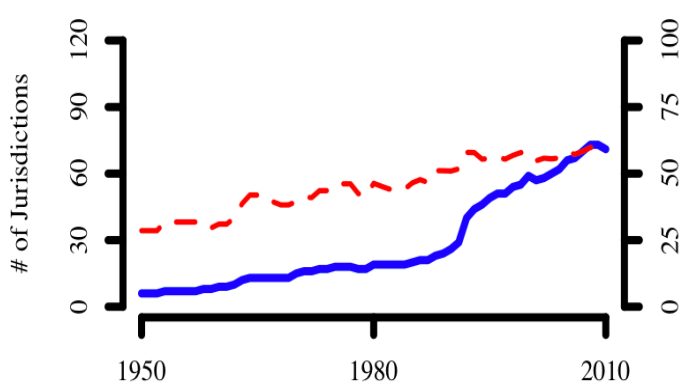

Imprisonment

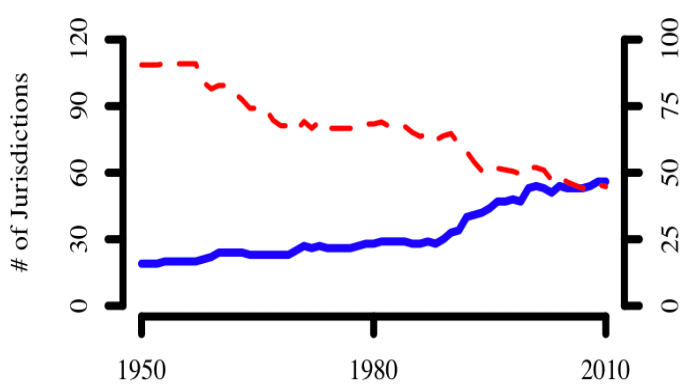

Damages

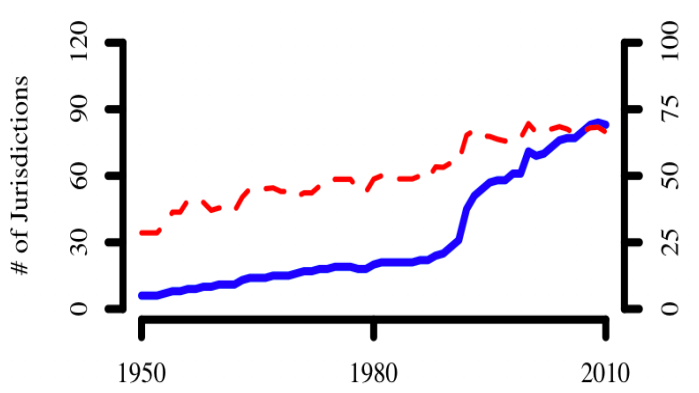

\# of Jurisdictions
Fines

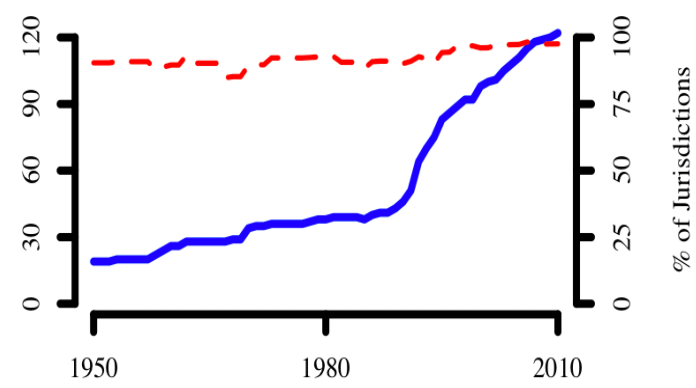

Divestitures

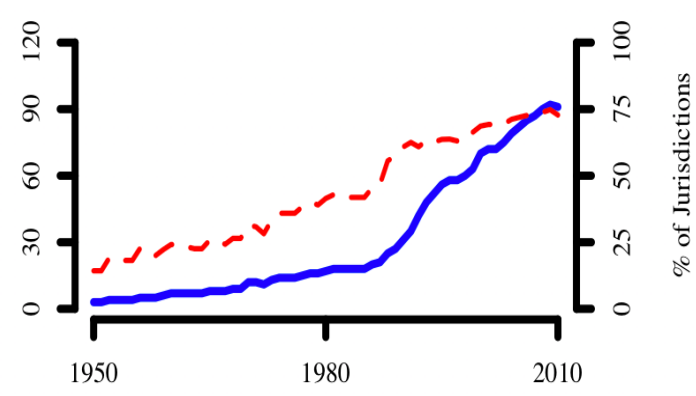

Extraterritoriality

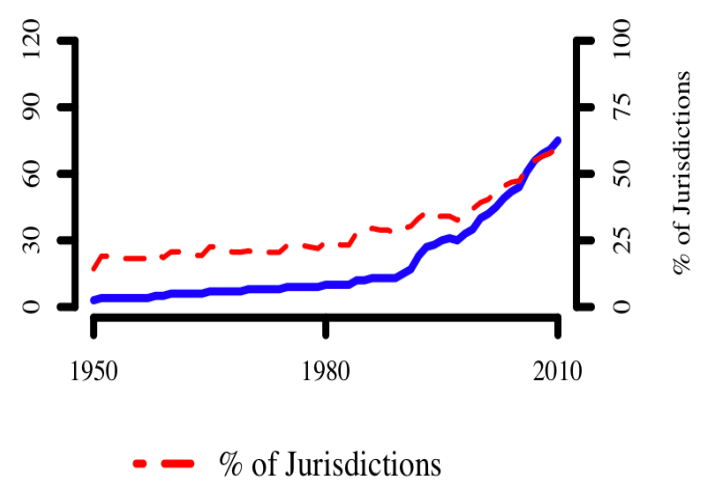


Figure 7: Comparative Competition Enforcement Dataset - Jurisdictions With Data

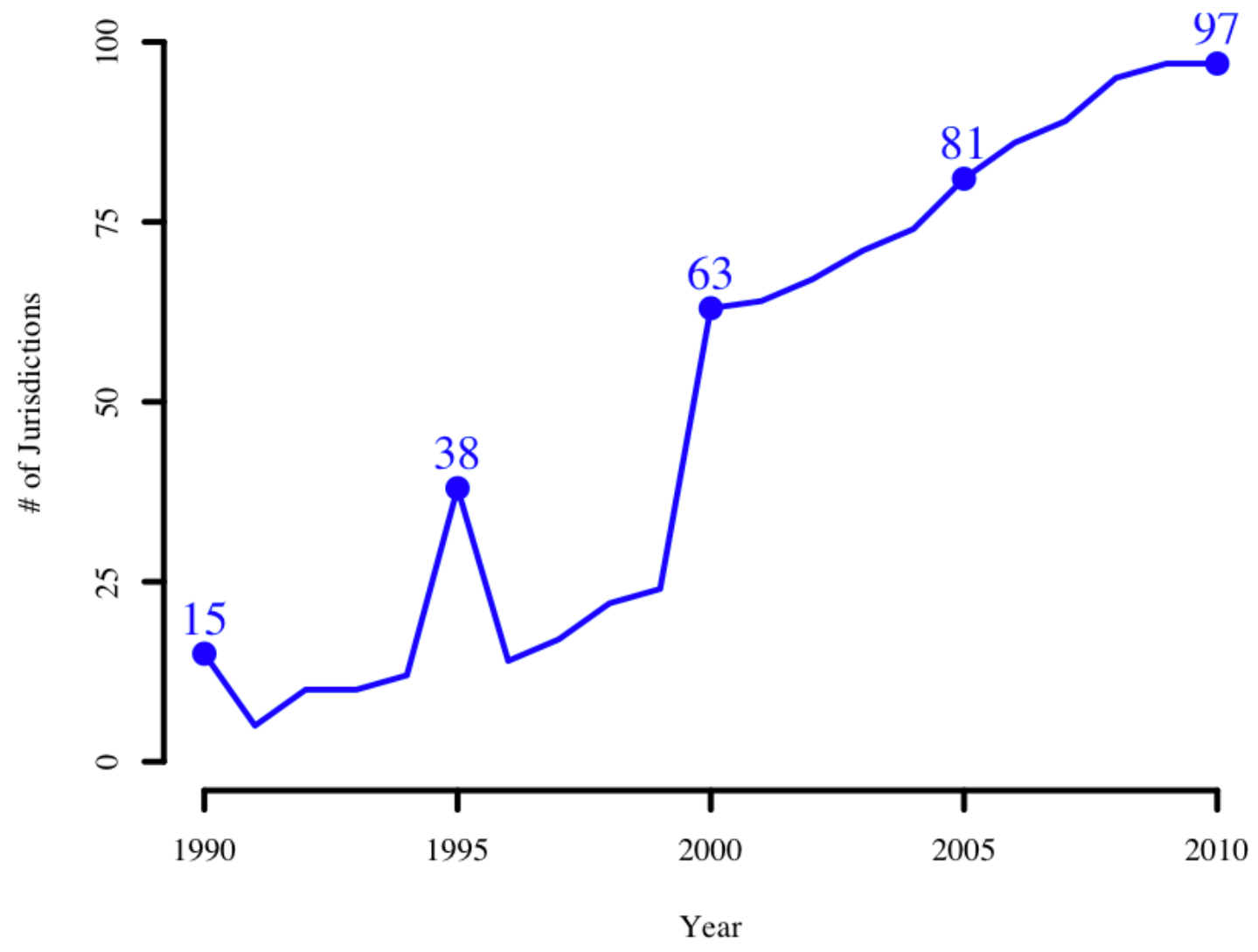


Figure 8: Comparative Competition Enforcement Dataset - Main Variables

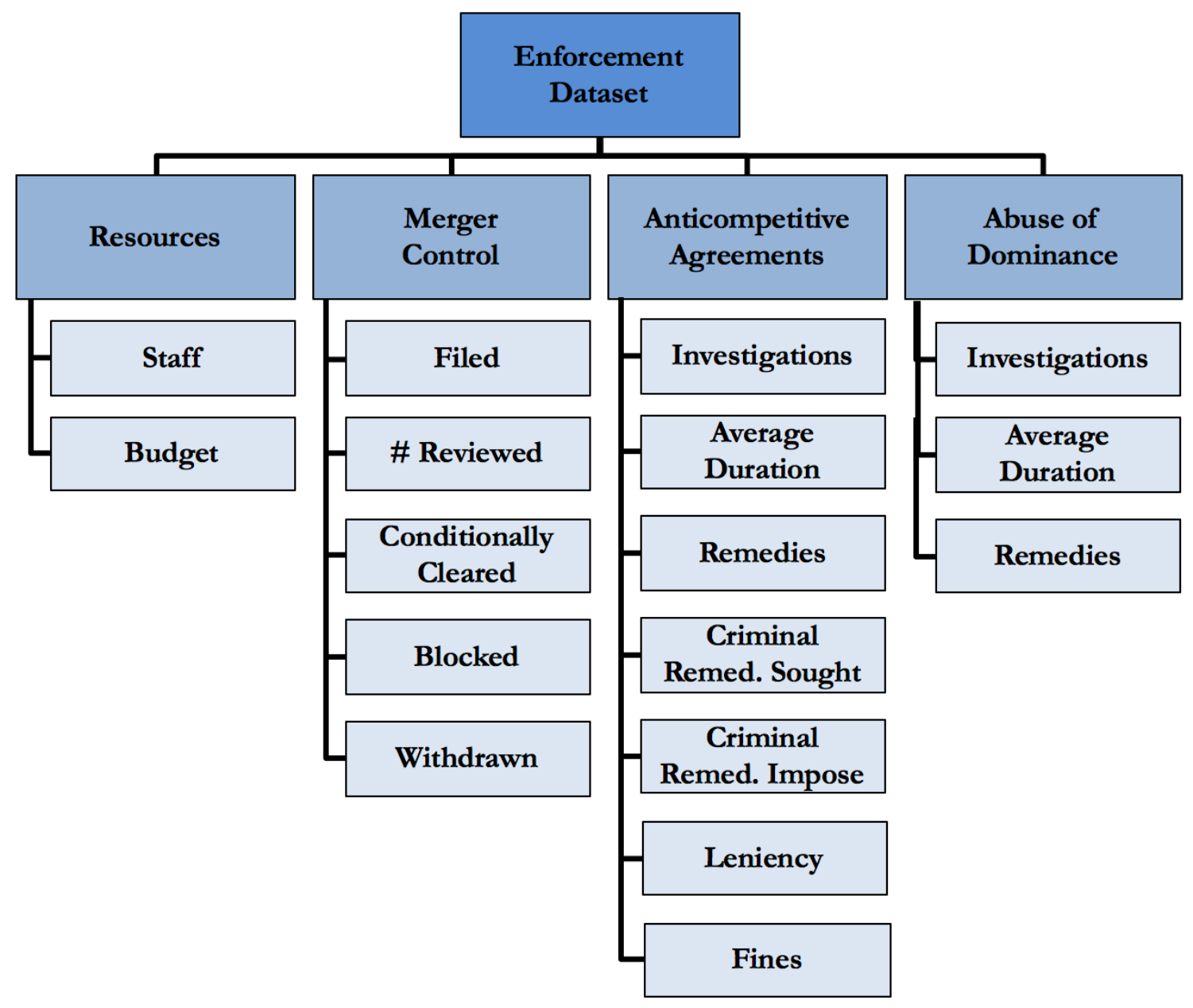


Figure 9: Comparative Competition Enforcement Dataset - Resources \& Activity
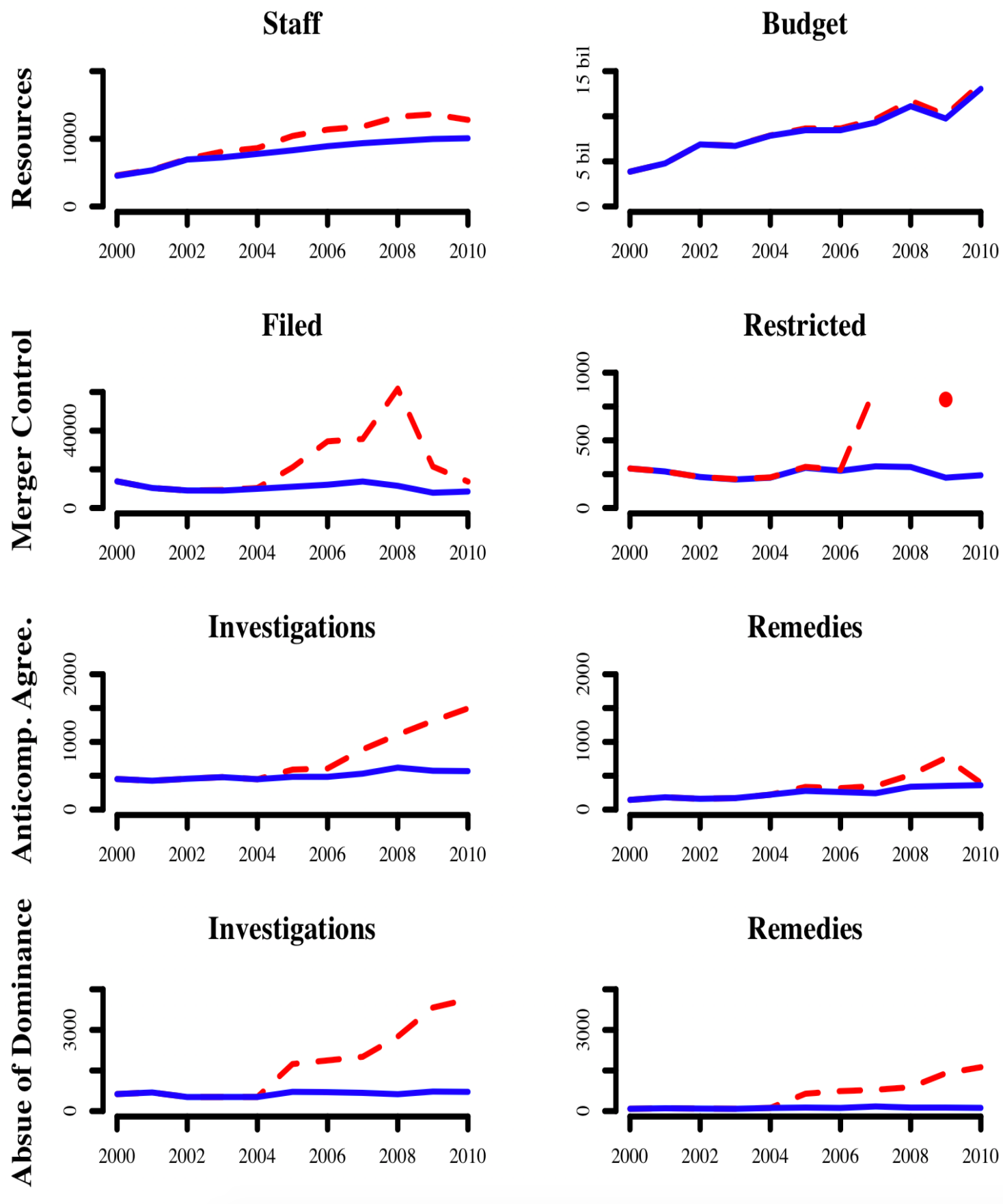

Remedies

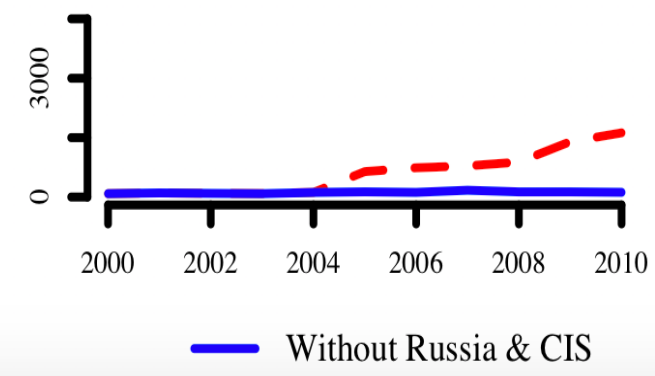


Figure 10: Comparative Competition Enforcement Dataset - Top Players
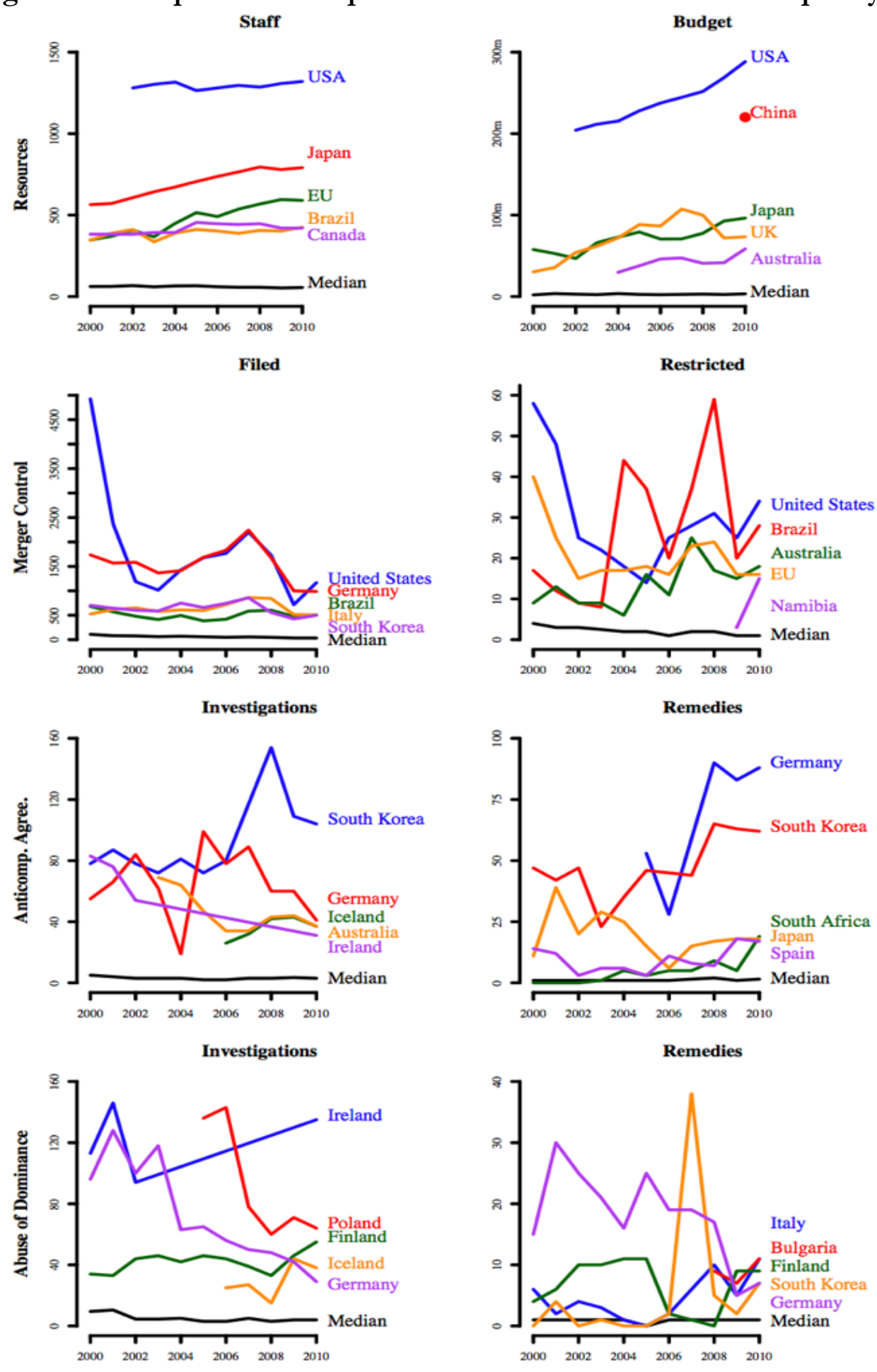
Figure 11: Merger Review by the United States and the European Union
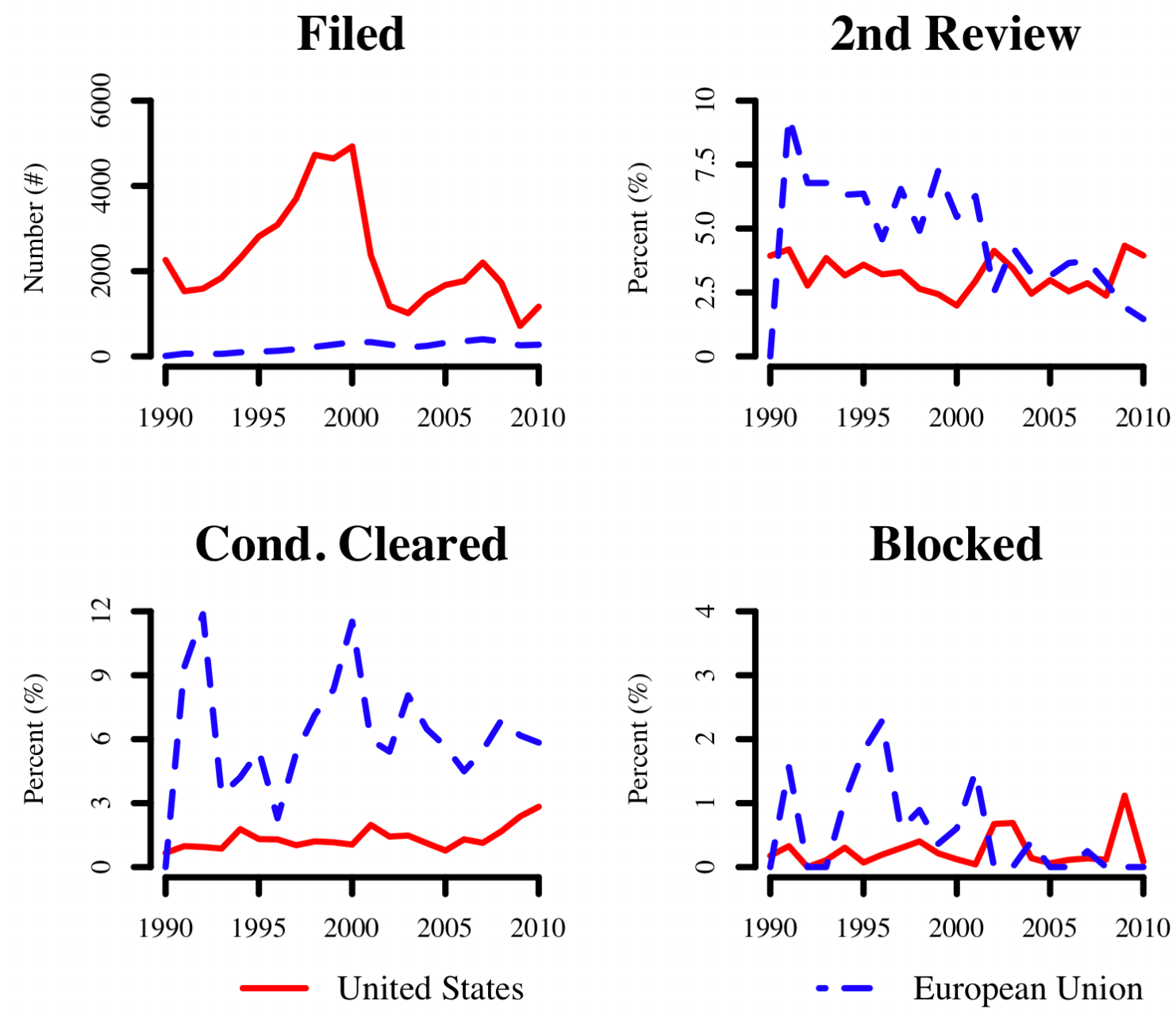


\section{Appendix 1: Jurisdictions in the Comparative Competition Datasets}

\begin{tabular}{|c|c|c|c|}
\hline Albania & Dominican Republic* & Kosovo* & Romania \\
\hline Algeria* & Egypt & Kuwait* & Russia \\
\hline Argentina & El Salvador & Kyrgyzstan* & Saudi Arabia \\
\hline Armenia & Estonia & Laos* & Senegal \\
\hline Australia & Ethiopia* & Latvia & Singapore \\
\hline Austria & European Union & Lithuania & Slovakia \\
\hline Azerbaijan & Fiji & Luxembourg & Slovenia \\
\hline Barbados & Finland & Macedonia & South Africa \\
\hline Belarus* & France & Madagascar* & South Korea \\
\hline Belgium & Gabon* & Malawi & Spain \\
\hline Benin* & Gambia* & Malaysia* & Sri Lanka* \\
\hline Bolivia* & Georgia & Mali & Sweden \\
\hline Bosnia and Herzegovina & German Federal Republic* & Malta* & Switzerland \\
\hline Botswana* & Germany & Mauritius & Syria* \\
\hline Brazil & Greece & Mexico & Taiwan \\
\hline Bulgaria & Greenland & Moldova & Tajikistan* \\
\hline Burkina Faso & Guatemala* & Mongolia & Tanzania \\
\hline Burundi* & Guyana* & Montenegro & Thailand \\
\hline $\mathrm{CAN}^{*}$ & Honduras & Morocco & Trinidad and Tobago* \\
\hline CARICOM & Hungary & Namibia & Tunisia \\
\hline COMESA* & Iceland & Nepal* & Turkey \\
\hline Cameroon & India & Netherlands & Ukraine \\
\hline Canada & Indonesia & New Zealand & United Kingdom \\
\hline Central African Republic* & Ireland & Nicaragua & United States of America \\
\hline Chile & Israel & Norway & Uruguay \\
\hline China & Italy & Pakistan & Uzbekistan* \\
\hline Colombia & Ivory Coast & Panama & Venezuela \\
\hline Costa Rica & Jamaica & Papua New Guinea & Vietnam \\
\hline Croatia & Japan & Peru & WAEMU* \\
\hline Cyprus & Jersey Channel Islands & Philippines & Yugoslavia \\
\hline Czech Republic & Jordan & Poland & Zambia \\
\hline Czechoslovakia & Kazakhstan & Portugal & Zimbabwe \\
\hline Denmark & Kenya & Qatar* & \\
\hline \multicolumn{4}{|c|}{ * Only in the Comparative Competition Law Dataset } \\
\hline ** Only in the Comparativ & ompetition Enforcement D & & \\
\hline
\end{tabular}


Appendix 2: Prior Efforts to Empirically Measure Competition Law

\begin{tabular}{|c|c|c|c|c|c|}
\hline Year & Author(s) & Article Name & $\begin{array}{c}\text { Metric for } \\
\text { Competition Law/Policy }\end{array}$ & $\begin{array}{l}\text { Years } \\
\text { Covered }\end{array}$ & $\begin{array}{c}\# \text { of } \\
\text { Countries } \\
\text { Covered }\end{array}$ \\
\hline 1997 & UNCTAD & $\begin{array}{l}\text { World Investment } \\
\text { Report 1997: } \\
\text { Transnational } \\
\text { Corporations, } \\
\text { Market Structure } \\
\text { and Competition } \\
\text { Policy }\end{array}$ & $\begin{array}{l}\text { The year competition law is } \\
\text { introduced. }\end{array}$ & $\begin{array}{l}\text { Binary for } \\
\text { first year of } \\
\text { policy }\end{array}$ & 79 \\
\hline 2000 & $\begin{array}{l}\text { Dutz, Mark and } \\
\text { Vagliasindi, } \\
\text { Maria }\end{array}$ & $\begin{array}{l}\text { Competition } \\
\text { Policy } \\
\text { Implementation in } \\
\text { Transition } \\
\text { Economies }\end{array}$ & $\begin{array}{l}\text { Competition law adoption, } \\
\text { enforcement, competition } \\
\text { advocacy and institutional } \\
\text { effectiveness. }\end{array}$ & 1997 & $\begin{array}{l}18 \text { (26 for law } \\
\text { adoption) }\end{array}$ \\
\hline 2005 & $\begin{array}{l}\text { Clougherty, } \\
\text { Joseph }\end{array}$ & $\begin{array}{l}\text { Antitrust Holdup } \\
\text { Source, Cross- } \\
\text { National } \\
\text { Institutional } \\
\text { Variation, and } \\
\text { Corporate Political } \\
\text { Strategy } \\
\text { Implications for } \\
\text { Domestic Mergers } \\
\text { in a Global } \\
\text { Context } \\
\end{array}$ & $\begin{array}{l}\text { Number of mergers } \\
\text { monitored, restructured, } \\
\text { prevented, or abandoned. }\end{array}$ & $1992-2000$ & 27 \\
\hline 2005 & $\begin{array}{l}\text { Krakowski, } \\
\text { Michael }\end{array}$ & $\begin{array}{l}\text { Competition } \\
\text { Policy Works: The } \\
\text { Effect of } \\
\text { Competition } \\
\text { Policy on the } \\
\text { Intensity of } \\
\text { Competition - An } \\
\text { International } \\
\text { Cross-Country } \\
\text { Comparison }\end{array}$ & $\begin{array}{l}\text { Experience in enforcing } \\
\text { competition law (measured } \\
\text { by years competition law in } \\
\text { place). Variable constructed } \\
\text { with the help of UNCTAD } \\
\text { (1997) data. }\end{array}$ & 2003-2004 & 101 \\
\hline $\begin{array}{l}2005- \\
2006\end{array}$ & $\begin{array}{l}\text { CUTS Civil } \\
\text { Society Report }\end{array}$ & $\begin{array}{l}\text { Competition } \\
\text { Regimes Around } \\
\text { the World }\end{array}$ & $\begin{array}{l}\text { Summaries of competition } \\
\text { legislation and } \\
\text { implementation around the } \\
\text { world. Cross-national raw } \\
\text { data but no systematic } \\
\text { metrics collected. }\end{array}$ & $\begin{array}{l}\text { Binary for } \\
\text { first year of } \\
\text { policy }\end{array}$ & 119 countries \\
\hline 2007 & $\begin{array}{l}\text { Hylton, Keith } \\
\text { \& Deng, Fei }\end{array}$ & $\begin{array}{l}\text { Antitrust Around } \\
\text { the World: An }\end{array}$ & $\begin{array}{l}\text { Antitrust Scope Index } \\
\text { (composite index based on }\end{array}$ & $2001-2004$ & 102 \\
\hline
\end{tabular}


Empirical Analysis substantive provisions in

of the Scope of competition laws (builds on

Competition Laws 2008 Nicholson index, and Their Effects developed in 2004)

\begin{tabular}{|c|c|c|c|c|c|}
\hline 2007 & $\begin{array}{l}\text { Kee, Hiau Looi } \\
\text { \& Bernard } \\
\text { Hoekman }\end{array}$ & $\begin{array}{l}\text { Imports, Entry } \\
\text { and Competition } \\
\text { Law as Market } \\
\text { Disciplines }\end{array}$ & $\begin{array}{l}\text { Competition law adoption, } \\
\text { enforcement resources } \\
\text { (staff/budgets), } \\
\text { investigations, cases } \\
\text { sanctioned, fines imposed. }\end{array}$ & $\begin{array}{l}2000 \text { (entire } \\
\text { study covers } \\
\text { years 1981- } \\
\text { 1998; but } \\
\text { competition } \\
\text { data only for } \\
\text { year 2000). } \\
\text { Analysis } \\
\text { relies on } \\
\text { binary } \\
\text { variable. }\end{array}$ & $\begin{array}{l}31 \text { (entire } \\
\text { study covers } \\
42 \text { countries) }\end{array}$ \\
\hline 2008 & Aiginger, Karl & $\begin{array}{l}\text { The Impact of } \\
\text { Competition on } \\
\text { Macroeconomic } \\
\text { Performance }\end{array}$ & $\begin{array}{l}\text { Composite indicator on the } \\
\text { "toughness of competition," } \\
\text { measured by } 13 \text { indicators, } \\
\text { some measuring competition } \\
\text { policy, others actual } \\
\text { competition (relies on } \\
\text { existing data but composite } \\
\text { indicator novel) }\end{array}$ & $\begin{array}{l}\text { Different } \\
\text { years for } \\
\text { different } \\
\text { variables - } \\
\text { generally } \\
\text { around } \\
2003-2006\end{array}$ & 26 \\
\hline 2008 & $\begin{array}{l}\text { Borrell, Joan- } \\
\text { Ramon \& Juan } \\
\text { Luis Jiménez }\end{array}$ & $\begin{array}{l}\text { The Drivers of } \\
\text { Antitrust } \\
\text { Effectiveness }\end{array}$ & $\begin{array}{l}13 \text { objective features of } \\
\text { competition policy across } \\
\text { four categories: (1) agency } \\
\text { independence, (2) cartels, (3) } \\
\text { dominance and (4) mergers. }\end{array}$ & 2004 & 47 \\
\hline 2008 & $\begin{array}{l}\text { Kronthaler, } \\
\text { Franz }\end{array}$ & $\begin{array}{l}\text { Effectiveness of } \\
\text { Competition Law: } \\
\text { An Empirical } \\
\text { Analysis }\end{array}$ & $\begin{array}{l}\text { The year competition law is } \\
\text { introduced. }\end{array}$ & $\begin{array}{l}\text { Binary for } \\
\text { first year of } \\
\text { policy }\end{array}$ & 84 \\
\hline 2008 & $\begin{array}{l}\text { Nicholson, } \\
\text { Michael }\end{array}$ & $\begin{array}{l}\text { An Antitrust Law } \\
\text { Index for } \\
\text { Empirical Analysis } \\
\text { of International } \\
\text { Competition } \\
\text { Policy (builds on } \\
2004 \text { FTC } \\
\text { working paper } \\
\text { series by the same } \\
\text { author) }\end{array}$ & $\begin{array}{l}\text { Antitrust Law Index } \\
\text { (composite index based on } \\
\text { substantive provisions in } \\
\text { competition laws) }\end{array}$ & 2003 & 52 \\
\hline 2009 & Seldeslachts, Jo & $\begin{array}{l}\text { Settle for Now but } \\
\text { Block for } \\
\text { Tomorrow: The }\end{array}$ & $\begin{array}{l}\text { Mergers notified, monitored, } \\
\text { settled and prohibited. }\end{array}$ & $1992-2005$ & 28 \\
\hline
\end{tabular}




\begin{tabular}{|c|c|c|c|c|c|}
\hline & & $\begin{array}{l}\text { Deterrence } \\
\text { Effects of Merger } \\
\text { Policy Tools }\end{array}$ & & & \\
\hline 2009 & Voigt, Stefan & $\begin{array}{l}\text { The Economic } \\
\text { Effects of } \\
\text { Competition } \\
\text { Policy - Cross- } \\
\text { Country Evidence } \\
\text { Using Four New } \\
\text { Indicators }\end{array}$ & $\begin{array}{l}\text { Indicator consisting of four } \\
\text { variables: (1) substantive } \\
\text { content of competition laws; } \\
\text { (2) degree to which laws are } \\
\text { based on economic analysis; } \\
\text { (3) formal independence of } \\
\text { agency; (4) factual } \\
\text { independence of agency. } \\
\text { Data generated via surveys } \\
\text { sent to competition agencies. }\end{array}$ & $\begin{array}{l}\text { Based on } \\
\text { "currently } \\
\text { valid } \\
\text { competition } \\
\text { law." }\end{array}$ & $\begin{array}{l}57 \text { countries } \\
\text { with } \\
\text { competition } \\
\text { law (plus } 37 \\
\text { countries } \\
\text { without) }\end{array}$ \\
\hline 2010 & $\begin{array}{l}\text { Clougherty, } \\
\text { Joseph }\end{array}$ & $\begin{array}{l}\text { Competition } \\
\text { Policy Trends and } \\
\text { Economic } \\
\text { Growth: Cross- } \\
\text { National } \\
\text { Empirical } \\
\text { Evidence }\end{array}$ & $\begin{array}{l}\text { Competition agencies' annual } \\
\text { budgets; ratio of economists } \\
\text { to lawyers employed by } \\
\text { authority; number of mergers } \\
\text { notified to authority }\end{array}$ & $1992-2007$ & 32 \\
\hline 2010 & Waked, Dina & $\begin{array}{l}\text { Antitrust } \\
\text { Enforcement in } \\
\text { Developing } \\
\text { Countries: } \\
\text { Reasons for } \\
\text { Enforcement \& } \\
\text { Non-Enforcement } \\
\text { using Resource- } \\
\text { Based Evidence }\end{array}$ & $\begin{array}{l}\text { Competition agencies' annual } \\
\text { budgets and staff. }\end{array}$ & $\begin{array}{l}\text { Adoption of } \\
\text { law- } 2009\end{array}$ & 40 \\
\hline 2011 & $\begin{array}{l}\text { Buccirossi, } \\
\text { Paolo et al. }\end{array}$ & $\begin{array}{l}\text { Measuring the } \\
\text { Deterrence } \\
\text { Properties of } \\
\text { Competition } \\
\text { Policy: The } \\
\text { Competition } \\
\text { Policy Indexes }\end{array}$ & $\begin{array}{l}\text { Competition Policy Indicator, } \\
\text { measuring quality and } \\
\text { intensity of competition } \\
\text { policy focusing on agency } \\
\text { features, resources, activity } \\
\text { levels, sanctions and quality } \\
\text { of law in the books. Data } \\
\text { generated via surveys sent to } \\
\text { competition agencies. }\end{array}$ & $1995-2005$ & 13 \\
\hline 2011 & Forslid et al. & $\begin{array}{l}\text { Trade costs and } \\
\text { timing of } \\
\text { competition policy } \\
\text { adoption }\end{array}$ & $\begin{array}{l}\text { The year competition law is } \\
\text { introduced. }\end{array}$ & $\begin{array}{l}\text { Binary for } \\
\text { first year of } \\
\text { policy }\end{array}$ & 24 \\
\hline 2013 & Petersen, Niels & $\begin{array}{l}\text { Antitrust Law and } \\
\text { the Promotion of } \\
\text { Democracy and }\end{array}$ & $\begin{array}{l}\text { The year competition law is } \\
\text { introduced. }\end{array}$ & 1960-2005 & 154 \\
\hline
\end{tabular}


Economic

Growth

\begin{tabular}{|c|c|c|c|c|c|}
\hline 2013 & OECD & $\begin{array}{l}\text { New Indicators of } \\
\text { Competition Law } \\
\text { and Policy in } 2013 \\
\text { for OECD and } \\
\text { Non-OECD } \\
\text { Countries }\end{array}$ & $\begin{array}{l}\text { Competition Law and Policy } \\
\text { Indicator, which is a } \\
\text { composite indicator } \\
\text { measuring (1) scope of } \\
\text { action, (2) policy in } \\
\text { substantive areas, (3) probity } \\
\text { of investigation, and (4) } \\
\text { competition advocacy Data } \\
\text { generated via survey sent to } \\
\text { competition agencies. }\end{array}$ & 2013 & 49 \\
\hline 2014 & $\begin{array}{l}\text { Gutmann, Jerg } \\
\text { \& Stefan Voigt }\end{array}$ & $\begin{array}{l}\text { Lending a Hand } \\
\text { to the Invisible } \\
\text { Hand? Assessing } \\
\text { the Effects of } \\
\text { Newly Enacted } \\
\text { Competition Laws }\end{array}$ & $\begin{array}{l}\text { The year competition law is } \\
\text { introduced. }\end{array}$ & 1971-2012 & $\begin{array}{l}119 \text { countries } \\
\text { with } \\
\text { competition } \\
\text { law (rest } \\
\text { without) }\end{array}$ \\
\hline 2016 & $\begin{array}{l}\text { Cremieux, } \\
\text { Pierre \& } \\
\text { Snyder, Edward }\end{array}$ & $\begin{array}{l}\text { Enforcement of } \\
\text { Anti-Collusion } \\
\text { Laws Against } \\
\text { Domestic and } \\
\text { Foreign Firms }\end{array}$ & $\begin{array}{l}\text { The total number of cartel } \\
\text { investigations where violation } \\
\text { found, nationalities of fined } \\
\text { firms, and the amount the } \\
\text { fines. }\end{array}$ & 1994-2014 & 2 \\
\hline 2017 & $\begin{array}{l}\text { Global } \\
\text { Competition } \\
\text { Review (GCR) }\end{array}$ & $\begin{array}{l}\text { Rating } \\
\text { Enforcement }\end{array}$ & $\begin{array}{l}\text { Resources of the competition } \\
\text { agencies (budget/staff); } \\
\text { investigations and remedies } \\
\text { across various areas of } \\
\text { enforcement activity. Data } \\
\text { generated via survey sent to } \\
\text { competition agencies. }\end{array}$ & $2001-2017$ & 37 \\
\hline 2018 & IMD & $\begin{array}{l}\text { World } \\
\text { Competitiveness } \\
\text { Yearbook }\end{array}$ & $\begin{array}{l}\text { Effectiveness of competition } \\
\text { legislation. } \\
\text { Data generated via survey } \\
\text { sent to executives. }\end{array}$ & 1989-2018 & $\begin{array}{l}\text { Varies but } 63 \\
\text { in } 2018 \\
\text { edition }\end{array}$ \\
\hline 2018 & $\begin{array}{l}\text { World } \\
\text { Economic } \\
\text { Forum }\end{array}$ & $\begin{array}{l}\text { Global } \\
\text { Competitiveness } \\
\text { Report }\end{array}$ & $\begin{array}{l}\text { Effectiveness of anti- } \\
\text { monopoly policy. Data } \\
\text { generated via survey sent to } \\
\text { executives. }\end{array}$ & 1979-2018 & $\begin{array}{l}\text { Varies but } \\
137 \text { in the } \\
2017-2918 \\
\text { edition }\end{array}$ \\
\hline
\end{tabular}

